\title{
The mTOR pathway in reproduction: from gonadal function to developmental coordination
}

\author{
Bibiana Correia ${ }^{1}$, Maria Inês Sousa ${ }^{1,2}$ and João Ramalho-Santos ${ }^{1,2}$ \\ ${ }^{1}$ CNC-Center for Neuroscience and Cell Biology, University of Coimbra, Coimbra, Portugal and ${ }^{2}$ Department of Life \\ Sciences, Calçada Martim de Freitas, University of Coimbra, Coimbra, Portugal \\ Correspondence should be addressed to / Ramalho-Santos; Email: jramalho@uc.pt
}

\begin{abstract}
Reproduction depends on many factors, from gamete quality to placenta formation, to fetal development. The mTOR pathway is emerging as a major player that integrates several cellular processes in response to a variety of environmental cues that are relevant in many aspects of reproduction. This review provides a general overview, summarizing the involvement of the two mTOR complexes (mTORC1 and mTORC2) in integrating signaling pathways, sensing environmental status, and managing physiological processes inherent to successful reproductive outcomes and pluripotent stem cell function. As a well-known governor of multiple cellular functions, it is not surprising that mTOR has a key regulatory role in determining cell quiescence or differentiation. In the gonads mTOR helps maintain spermatogonial stem cell and follicle identity and tightly regulates differentiation in both systems to ensure proper gamete production. The mTOR pathway is also known to prevent premature follicle exhaustion, while also controlling the blood-testis barrier in the male gonad. In stem cells mTOR again seems to have a role in controlling both pluripotency and differentiation, mirrored by its in vivo roles in the embryo, notably in regulating diapause. Finally, although there are clearly more complex systems intertwined in placental function, mTOR seems to serve as an early checkpoint for development progression and successful implantation.

Reproduction (2020) 159 R173-R188
\end{abstract}

\section{Introduction}

Gamete production involves a series of complex meiotic processes, which occur in parallel with extensive morphological and physiological changes. Following fertilization, the one-cell zygote undergoes mitotic divisions culminating in blastocyst formation, accompanied by constant alterations in metabolism (Gardner \& Harvey 2015), signaling pathways, chromatin arrangement and cell fate decisions (Bedzhov et al. 2014, Weinberger et al. 2016). In the blastocyst, the two first lineages are already segregated into the inner cell mass (ICM) and the trophectoderm (TE). The former will contribute to the embryonic tissues, and the latter, upon implantation, will contribute to the placenta that dynamically supports further development. In all these processes there is a constant need for tightly controlled cell divisions and precise environmental sensing, to ensure the quality of development.

The TOR protein was discovered in 1991 in the budding yeast, Saccharomyces cerevisiae, while uncovering the mechanism of action of rapamycin (Heitman et al. 1991), an efficient antiproliferative drug. A few years later, the mammalian analog of TOR was isolated and named mammalian Target Of Rapamycin (mTOR; Brown et al. 1994, Sabatini et al. 1994) or mechanistic Target Of Rapamycin. As a major player in cell signaling, mTOR coordinates several fundamental processes such as cytoskeletal organization (Jacinto et al. 2004, Sarbassov et al. 2004), cell survival (Stambolic et al. 1998, Hirose et al. 2014), autophagy (Nicklin et al. 2009, Koren et al. 2010), lipid synthesis (Li et al. 2011, Peterson et al. 2011), protein synthesis (Ma \& Blenis 2009, Laplante \& Sabatini 2012) and the cell cycle (Fingar et al. 2004, Gao et al. 2004, Chatterjee et al. 2015), among others (Fig. 1). More importantly, outcomes of these distinct pathways depend on key environmental cues, including the presence/absence of growth factors (Laplante \& Sabatini 2012), oxygen/hypoxia (Brugarolas et al. 2004, DeYoung et al. 2008), energy status (Inoki et al. 2003a), nutrients (Kim et al. 2002, 2008, Smith et al. 2005) and other stressors (Fig. 1). This complex integration of diverse stimuli has an important role in cell homeostasis, proliferation and differentiation. Consequently, mTOR signaling impairment can lead to severe physiological dysfunction at many levels. Considering the global nature of this signaling pathway, this review aims to integrate the role of mTOR in reproduction, providing a brief overview of its importance, from gonads and gametes, to embryos, stem cells and the placenta. 


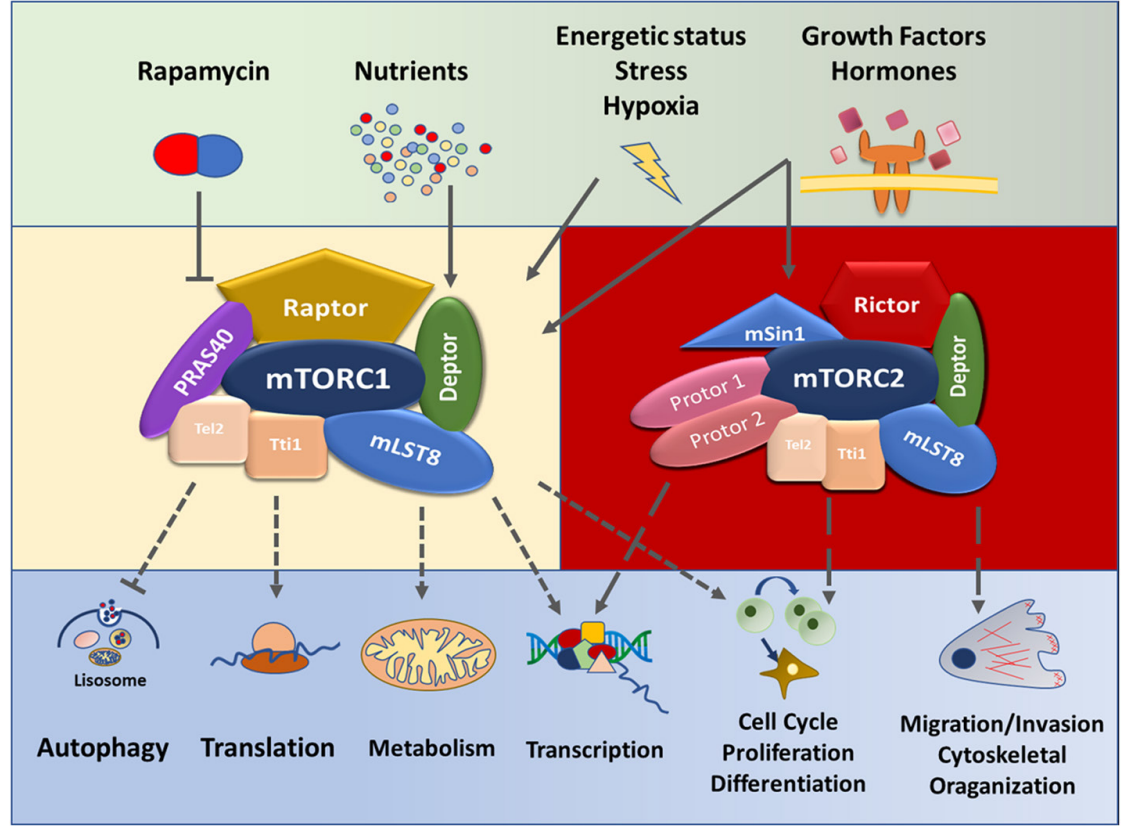

Figure 1 The integrative role of the mTOR pathway on cellular homeostasis. mTORC1 and mTORC2 assemble differently, relying on particular allies to respond to distinct stimuli and accordingly regulate specific cellular outcomes.

\section{mTOR: more complex than just a protein}

mTOR is a highly conserved protein that belongs to the phosphoinositide 3-kinase (PI3K)-related kinase family. The ability of this serine/threonine kinase to sense different cues and interact with particular cellular targets is dependent on its ability to interact with other proteins, forming two multimeric complexes - mTORC1 and mTORC2. RAPTOR is mandatory for the assembly of the mTORC1 complex (Kim et al. 2002, Sancak et al. 2007). On the other hand, the assembly of the mTORC2 complex relies on mSIN1 and RICTOR(Sarbassov et al. 2004) and on RICTOR association with PROTOR 1/2 (Pearce et al. 2007, 2011). Regardless of being assembled with the partners that characterize mTORC1 or $\mathrm{mTORC2}$, the mTOR protein is capable of binding to mLST8, DEPTORr and the Tti1/Tel2 complex (Laplante \& Sabatini 2012).

mTORC1 is sensitive to growth factors, hypoxia, energy status (via AMPK activity) and nutrients. Consequently, mTORC1 activity promotes translation and protein synthesis, mainly through two mTORC1 substrates: ribosomal protein $\mathrm{S} 6$ kinases (S6Ks) and eukaryotic translation initiation factor 4E-binding protein 1 (4EBP1; Ma \& Blenis 2009, Laplante \& Sabatini 2012). Furthermore, mTORC1 promotes lipid biosynthesis by modulating the activity of SREBP $1 / 2$ (Li et al. 2011, Peterson et al. 2011) and PPARG (Kim \& Chen 2004, Zhang et al. 2009). On the other hand, autophagy is negatively regulated by mTORC1 via several mechanisms (Laplante \& Sabatini 2012), namely, by activating the autophagy suppressor DAP1 (Koren et al. 2010), and also by regulating TFEB and preventing lysosome biogenesis (Settembre et al. 2012). Additionally, mTORC1 regulates glucose metabolism and mitochondrial function by modulating HIF1A and PGC1A (Brugarolas et al. 2003, Cunningham et al. 2007, Düvel et al. 2010).

Growth factors activate PI3K- or Ras-dependent signaling pathways that, in turn, can regulate mTORC1, leading to TSC1 and TSC2 complex phosphorylation, inactivating its GAP activity (Inoki et al. 2002, Manning et al. 2002, Tee et al. 2003). This triggers the Rheb GTPase, which in its GTP-bound state (Inoki et al. 2003b) directly activates mTORC1, via phosphorylation (Inoki et al. 2002, Manning et al. 2002, Potter et al. 2002, Long et al. 2005, Sancak et al. 2007). On the other hand, AMPK is sensitive to the AMP:ATP ratio, making AMPK a major cellular energy sensor (Shackelford \& Shaw 2009, Hardie et al. 2012). Accordingly, when this ratio increases, AMPK also activates mTORC1, and other stressors such as DNA damage may also regulate mTORC1 via the regulation of REDD1 (Brugarolas et al. 2004, DeYoung et al. 2008). Moreover, amino acid availability was shown to regulate mTORC1 similar to its inhibitor rapamycin (Hara et al. 1998). Amino acid withdrawal leads to dephosphorylation of direct mTORC1 targets S6K1 and 4EBP1, inhibiting mRNA translation (Hara et al. 1998), an effect that is reversed upon amino acid reconstitution in cell culture media. Although the exact mechanism of how amino acid availability activates mTORC1 is still unclear, pathways involving Rag GTPases (Kim et al. 2008) or biogenic polyamines have been proposed (Zeng et al. 2013, Ray et al. 2015). However, it should be noted that not all amino acids display the same efficiency in stimulating mTORC1 (Hara et al. 1998, Long et al. 2005). Finally, impairment in the transport or the lack of amino acids also affects cell proliferation in an mTOR -dependent 


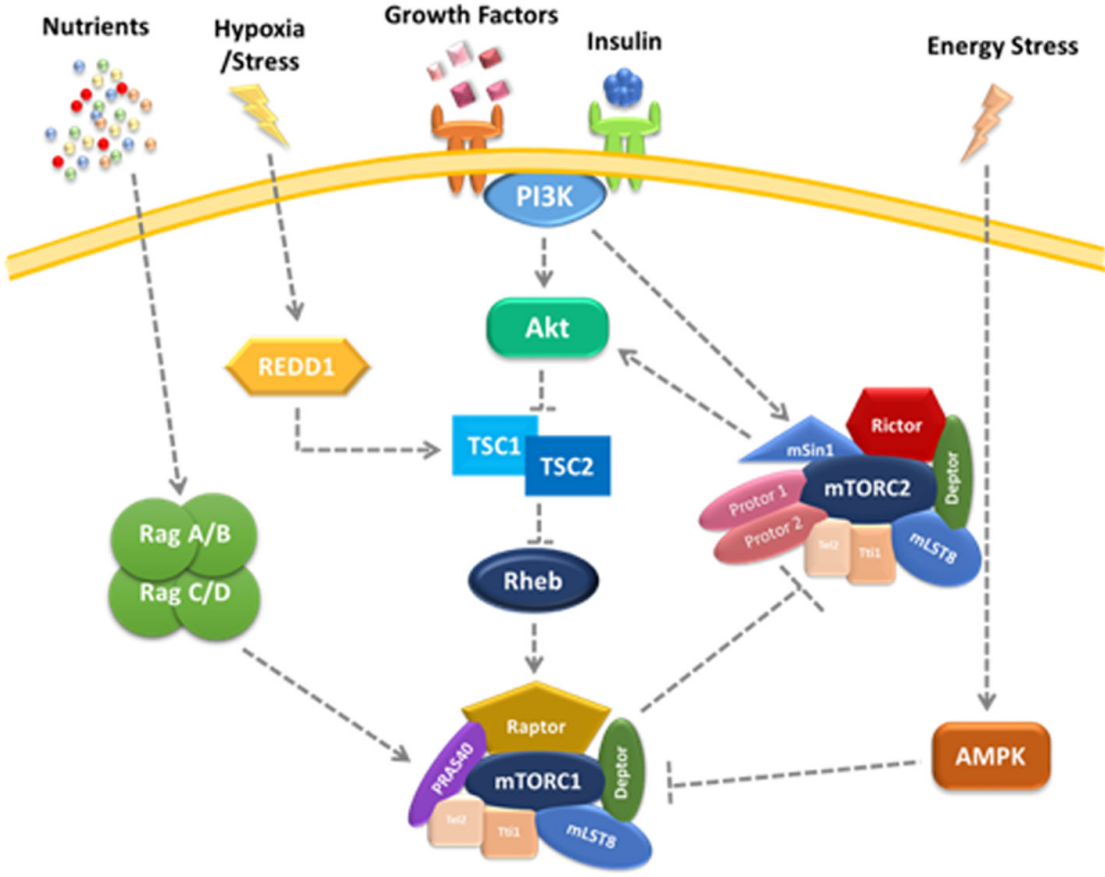

Figure 2 Upstream signals that affect mTOR regulation. Different stimuli, namely, growth factors and hormones, insulin, energy stress (AMP/ATP ratio), hypoxia and nutrient availability, are known to modulate mTORC1 and mTORC2 differently, acting through different signaling cascades. manner (Smith \& Proud 2008, Nicklin et al. 2009, González et al. 2012) (Fig. 2).

In contrast to mTORC1, mTORC2 is less well understood, although it is known to be activated in a $\mathrm{PI} 3 \mathrm{~K}$-dependent fashion and thus is also responsive to growth factors. Furthermore, its main targets are AKT, SGK1 and PKCA, thus regulating cell survival and growth (Stambolic et al. 1998, Laplante \& Sabatini 2012), ion transport (Potter et al. 2002, García-Martínez \& Alessi 2008) and cell shape through cytoskeletal reorganization (Jacinto et al. 2004, Sarbassov et al. 2004). mTORC2 has also an indirect role in metabolism, not only in terms of mitochondrial physiology (Betz et al. 2013) but also by being able to control glucose metabolism in AKTdependent (Hagiwara et al. 2012, Roberts et al. 2013, Masui et al. 2014) and FOXO-dependent (Hagiwara et al. 2012, Masui et al. 2013) manners. Finally, mTORC2 is also able to modulate the hexosamine biosynthetic pathway (Moloughney et al. 2016), thus affecting protein and lipid glycosylation, as well as glutamine metabolism (Boehmer et al. 2003, Moloughney et al. 2016), both involved in anabolic processes.

It should be noted that both mTOR complexes can intrinsically regulate each other via a feedback mechanism that has not been completely characterized. Of the known mTORC2 targets, AKT is the most intensively studied, followed by mTORC2-mediated serine 473 phosphorylation. Further, AKT targets TSC2, resulting in mTORC1 activation (Laplante \& Sabatini 2012). In contrast, mTORC1 can limit mTORC2 activity by stimulating S6K1, that can, in turn, inactivate mTORC2 by direct phosphorylation of mSIN1 (Liu et al. 2013) and RICTOR (Julien et al. 2010, Fig. 2).

\section{(Sper)mTOR: mTOR activity in testicular function}

Infertility is classically defined as the inability to conceive after frequent and unprotected sexual intercourse for over a year (WHO 2010). It affects about $10 \%$ of couples worldwide (Mascarenhas et al. 2012), and approximately $50 \%$ of all cases are attributed to the male partner (WHO 2010, Miyamoto et al. 2012). During spermatogenesis, spermatogonia undergo a few mitotic divisions and then differentiate into primary spermatocytes that undergo meiotic divisions to yield haploid spermatids, which differentiate to mature spermatozoa (Holstein et al. 2003, Cheng \& Mruk 2012). Unsurprisingly, this process is highly controlled by a wide range of signaling pathways, including mTOR.

The first evidence of a possible impact of mTOR on male fertility was related to the clinical report of an immune-compromised patient due to sirolimus (rapamycin) treatment, showing a dramatic decrease in sperm quality, namely, sperm count (oligospermia), percentage of normal-shaped sperm (teratospermia) and sperm motility (asthenospermia). Importantly, these negative effects of rapamycin treatment were completely reversible (Bererhi et al. 2003). In line with these effects on sperm quality, several case reports subsequently showed that rapamycin treatment led to decreased testosterone levels and increased levels of $\mathrm{FSH}$ and $\mathrm{LH}$, reinforcing the hypothesis that this mTOR inhibitor could be having an adverse effect on testicular function (Fritsche et al. 2004, Lee et al. 2005). These patients also had severe oligoasthenospermia and in some cases complete azoospermia (complete lack of sperm in the ejaculate), which, again, was reversible 
after the treatment ended (Deutsch et al. 2007, Skrzypek \& Krause 2007, Zuber et al. 2008, Boobes et al. 2010).

In agreement with these reports, rats exposed to rapamycin presented lower testicular weight and a decreased seminiferous tubule area. Additionally, in the testes of these animals, only spermatogonia were found but not spermatocytes or spermatids, suggesting that mTOR inhibition blocked spermatogenesis at the spermatogonial level (Rovira et al. 2012). Rapamycintreated rats presented not only smaller and vacuolated seminiferous tubules butalso decreased sperm production and blocked spermatogonial cell cycle progression (with increased percentage of spermatogonial cells in G1), suggesting inhibited spermatogonia proliferation that could explain the impaired sperm production, although entry into meiosis might also be affected (Xu et al. 2016).

Indeed, in mice, rapamycin decreased the expression of meiotic markers, suggesting that mTOR inhibition maintains spermatogonia in the undifferentiated state (Busada et al. 2015, Sahin et al. 2018). More importantly, a spermatogonial-specific over-activation of the mTORC1 complex led to testicular development defects, sperm count reduction and increased germ cell apoptosis. In addition, mTORC1 activation induced spermatogonial differentiation, which, combined with increased germ cell apoptosis, resulted in the depletion of the germ cell pool (Hobbs et al. 2010, Zhou et al. 2015, Wang et al. 2016). It is therefore unsurprising that a conditional germ cell mTOR knockout (cKO) resulted in smaller testes with abundant spermatogonia and no apparent spermatocytes, confirming impairment in germ cell differentiation. Interestingly, a subset of undifferentiated spermatogonia in the mTOR cKO mouse could still self-renew, suggesting that mTOR is dispensable for the maintenance of undifferentiated spermatogonia but necessary for differentiation and spermatogenesis (Serra et al. 2017). In agreement with this observation, differentiation-prone spermatogonia have elevated mTORC1 activity, when compared to their undifferentiated stem cell counterparts, suggesting that mTORC1 may negatively regulate spermatogonial stem cell self-renewal (Hobbs et al. 2015).

It is clear that mTOR is highly involved in spermatogenesis; however, the exact mechanism by which it impacts the spermatogonial pool is still under discussion, as some studies have shown that mTOR modulation impacts spermatogonial proliferation and apoptosis, while others suggest that it is not a major player in self-renewal but is crucial for spermatogonial differentiation. Another important fact to consider is that the various methodological approaches used in different papers resulted in different rates of modulation for each of the mTOR complexes, leading to distinct outcomes. Nonetheless, a germ cell-specific Rictor cKO mouse model presented significant spermatogenesis impairment, with some tubules exhibiting the loss of germ cell hierarchy including elongated spermatids at the basal membrane, while other tubules were germ cell-depleted, probably due to an increase in preleptotene and leptotene spermatocyte apoptosis. Importantly, the loss of Rictor caused an upregulation of cell adhesion and migration-associated genes in Sertoli cells, suggesting that mTOR has a role in not only the regulation of spermatogonial proliferation but also the integrity of the blood-testis barrier (BTB; Bai et al. 2018).

The BTB is formed by adjacent Sertoli cells at the basement membrane of the seminiferous tubules with intercellular spaces sealed by tight junctions (TJs) at the apical region, while ectoplasmic specialization (ES) junctions, namely, adherens junctions (AJs), provide links not only between Sertoli cells but also between Sertoli and germ cells (Mok et al. 2013a). In addition, the basal region of the BTB depends on desmosomes and gap junctions (GJs) for its cohesion (Cheng \& Mruk 2012, Mok et al. 2013a).

The BTB undergoes cyclic reconstruction during spermatogenesis, to allow the transit of preleptotene spermatocytes into the adluminal region during stages VIII to XI of the testicular epithelial cycle (Mok et al. $2013 a, b)$. The mTOR protein is highly expressed at the BTB, suggesting an important role in its modulation, and over-activation by conditional deletion of TSC1 led to mislocalization of several proteins involved in testicular junctional complexes (Tanwar et al. 2012). Furthermore, phosphorylated pS6, a downstream target of mTORC1, is expressed specifically at late stages VII and $\mathrm{XI}$ of the spermatogenic cycle and is co-localized with several proteins of the BTB, namely, ZO-1 (a TJ-associated protein), $\mathrm{N}$-cadherin (an ES protein) and F-actin, in a stage-specific manner (Mok et al. 2012, 2015). Importantly, the inhibition of mTORC1 by rapamycin and $S 6$ Knockdown (cKD), not only strengthened the BTB by increasing the expression of TJ-associated proteins but also increased the proportion of F-actin bundle alignments (Mok et al. 2012). This suggests that the activation of the mTORC1 complex is necessary to weaken the BTB and allow the transit of preleptotene spermatocytes to the adluminal region of the seminiferous tubules (Mok et al. 2012, 2015).

On the other hand, the mTORC2 complex protein, RICTOR is partially co-localized with TJ proteins, and its expression shifts with the seminiferous cycle stage. Although both RICTOR and mTOR are highly expressed at stages $\mathrm{V}$ to $\mathrm{VI}$, at stage $\mathrm{VII}$, RICTOR expression starts to decline until it is barely detectable at stages VIII to IX. To note, the high mTOR expression throughout these late stages supports the hypothesis that mTORC2 assembly is required in the first stages of the spermatogenic cycle to maintain the integrity of the BTB but is dispensable and downregulated during stages VIII and IX, when the barrier restructuring takes place (Mok et al. 2013b). Interestingly, when Rictor was conditionally knocked down in Sertoli cells, there was no downregulation of TJ proteins, but these proteins were mis-localized 
from the Sertoli-Sertoli interface. Moreover, F-actin bundles were disorganized, suggesting that mTORC2 assembly is important for the maintenance of a cohesive BTB (Mok et al. 2013b). In accordance, Rictor cKO mice had severe testicular defects, as they had no seminiferous lumen or elongated spermatids and, more importantly, presented a loss of germ cell hierarchy in the seminiferous epithelium (Dong et al. 2015) that could explain the resulting azoospermia. In agreement, Mok et al. (2013b) reported that Rictor ablation did not change the protein levels of occluding (TJ protein), $\mathrm{N}$-cadherin or actin-related protein complex 2 (Arpc2) but altered their localization, weakening the BTB (Dong et al. 2015). Interestingly, mTOR cKO in Sertoli cells produced a similar disorganization of the seminiferous epithelium, which seemed to be due to a redistribution of the BTB gap junction protein 1 (GAP-1) (Boyer et al. 2016). Thus, the mTOR pathway is a major regulator of the BTB permeability, given that a timely activation of both mTORC1 and 2 is required to maintain a cohesive and flexible barrier.

In summary, the mTOR pathway is involved in spermatogenesis, by regulating spermatogonial germ cell proliferation and apoptosis and by tightly controlling BTB function. However, further research is still needed to evaluate the effect, if any, of mTOR on the differentiated functional sperm cell (Silva et al. 2019). It is intriguing to speculate that an effect of mTOR on male fertility may be in some way related to energy sensing and nutrient availability, which could condition male investment in gamete production, depending on environmental cues. Considering that after ejaculation sperm must travel through the female reproductive tract to fertilize the oocyte and that the mTOR pathway is regulated by hypoxia and extracellular $\mathrm{pH}$, it would be interesting to assess how the female reproductive tract environment could modulate sperm function.

\section{mTOR in female reproduction: keep it slow or speed it up}

Following the migration and establishment of primordial germ cells (PGCs) in the developing ovary, a process named primordial follicle assembly takes place, in which PGCs are surrounded by somatic cells (namely, squamous granulosa cells (GCs)). When squamous GCs assume a cuboid morphology, the primary follicle is formed. The GCs start to proliferate and recruit steroidogenic cells (theca cells), leading to the secondary follicle formation. The antral follicle is characterized by the appearance of a cavity filled with follicular fluid (antrum), which divides two populations of GCs: the more external mural GCs and the cumulus GCs. This follicle growth will give rise to the pre-ovulatory Graafian follicle. Female meiosis is initiated during fetal development, and the oocytes enclosed in primordial and primary follicles are arrested in diplotene of prophase I, also known as the germinal vesicle (GV) stage. After primary follicle activation, GV envelope breaks down (GVBD) and meiosis progresses until it is once again arrested at metaphase II. It is at this stage that oocytes are ovulated in most mammals, and meiosis is completed only if fertilization takes place.

The PI3K/AKT/mTOR pathway regulates events that involve follicle quiescence, activation, development, proper oocyte maturation and ovulation. Because this pathway responds to several growth factors and hormones, it is not surprising that it is sensitive to $\mathrm{LH}$ signaling in theca cells (Palaniappan \& Menon 2010, 2012) and FSH signaling in GCs (Kayampilly \& Menon 2007, Sirotkin et al. 2015). Several studies suggest that mTOR is a positive regulator of GC proliferation (Kayampilly \& Menon 2007, Yaba et al. 2008, Yu et al. 2011); follicular survival, activation and development (Cheng et al. 2015, Zhang et al. 2017a, Li \& Liu 2018); and translation of maternal transcripts (Chen et al. 2013). Furthermore, its deregulation is associated with follicular atresia and ovarian function impairment (Choi et al. 2014, Chen et al. 2015a). For those outcomes, communication between oocytes and GCs is of utmost importance. In oocytes the disruption of the negative regulators of mTORC1 TSC1 (Adhikari et al. 2010) or TSC2 (Adhikari et al. 2009) led to the over-activation of primordial follicles and infertility. This reinforces the notion that mTOR activity through oocyte-GC communication is crucial to maintain primary follicles in a quiescent state. On the other hand, Rictor cKO on oocytes showed that mTORC2 activity seems to be mostly associated with follicle survival in an oocyte-dependent fashion (Chen et al. 2015a). Moreover, the fact that $m T O R$ CKO in primordial oocytes causes a shift in GCs morphology to an immature Sertoli cell-like phenotype, including the expression of genes characteristic of this testicular cell type (Guo et al. 2018), suggests that the communication between oocytes and the surrounding GCs is crucial to sustain cellular identity, although not much is known about how exactly mTOR is regulating this.

Given these results, mTOR has emerged as a putative target to ameliorate either fertility dysfunction related to premature follicle pool loss or exhaustion of the oocyte pool, and therefore in modulating aging-specific effects. Thus, several rodent models of premature ovarian failure (POF) and primary ovarian insufficiency (POI) conditions, characterized by premature follicle depletion, revealed that mTOR deregulation led to anomalous primary follicle activation (Adhikari et al. 2009, 2010, 2013, Sherman et al. 2014). Furthermore, rapamycin restricts the transition from primordial to developing follicles in rodent models, reducing follicular atresia and extending ovarian lifespan by downregulating mTOR activity and increasing SIRT activity, similar to caloric restriction (Luo et al. 2013, Zhang et al. 2013). However, although prolonged rapamycin exposure delays follicle pool 
exhaustion, it has detrimental consequences on murine ovarian function and thus on the reproductive cycle, which may be overcome by transient treatments of rapamycin (Dou et al. 2017), although possible persistent side effects require further attention.

Furthermore, in terms of putative effects on gametogenesis, it is important to mention that mTOR disruption has been reported to cause errors during meiotic and mitotic chromosome disjunction (Lee et al. 2012, Yu et al. 2012, Dou et al. 2017). In interphase GCs mTOR has a predominant cytoplasmic distribution (as is the case for its phosphorylated form) but is also found in the nuclei. In contrast, during prophase, its localization shifts to the vicinity of chromosomes and becomes more intense in the spindle during metaphase and cytokinesis (Kogasaka et al. 2013). Interestingly, RAPTOR, part of mTORC1, co-localizes with mTOR in all these phases of the mitotic process (Yu et al. 2011, Kogasaka et al. 2013), while mTORC2-specific RICTOR seems to be dissociated from mTOR throughout mitosis (Kogasaka et al. 2013). This indicates that mTORC1 and mTORC2 are differentially active, not only during mitosis in GCs but also during meiosis in oocytes. In mature metaphase II oocytes mTOR localization at the spindle (Lee et al. 2012, Kogasaka et al. 2013) may be related to its repressive effect on autophagy, given that low levels of autophagy are observed in oocytes, increasing dramatically upon fertilization (Tsukamoto et al. 2008). Despite all the correlative evidence concerning mTOR localization during meiosis, it is still unknown if the effects are directly related to mTOR function in situ or are a consequence of its activity in previous phases of oocyte development.

\section{mTOR and early embryo development}

After fertilization the totipotent zygote undergoes mitosis, and the 8- to 16-blastomere embryo experiences a process known as compaction (Ziomek \& Johnson 1980, Fierro-González et al. 2013). Accordingly, an outer layer of polarized and non-polarized blastomeres is defined, surrounded by more internal cells containing non-polar blastomeres (Yamanaka et al. 2010, McDole et al. 2011). In the 32-blastomere-compacted morula, there is evidence that cells are already more committed to one of the two first embryo cell lineages: the outer cells will give rise to the trophectoderm (TE), and the inner cells to the pluripotent ICM (McDole et al. 2011, Goolam et al. 2016, Posfai et al. 2017). As development proceeds, pluripotency genes are gradually restricted to internal non-polarized cells via TEAD4 activity (Yagi et al. 2007, Nishioka et al. 2008). Thus, TE cells will be specified by $C d \times 2$ (Nishioka et al. 2009, Schrode et al. 2013) and Gata3 (Ralston et al. 2010, Schrode et al. 2013) expression, whereas the ICM will be specified by the expression of Oct4, also known as Pou5f1 (Nichols et al. 1998, Nichols \& Smith 2012), Nanog (Chambers et al. 2003, Mitsui et al. 2003) and Sox2 (Avilion et al. 2003).

Within the compacted morula a cavity full of fluid (the blastocoel) forms, giving rise to the blastocyst, in which TE cells are arranged side to side in a more external layer of the embryo, surrounding both the ICM and the blastocoel (Bedzhov et al. 2014). The transition from early to late blastocyst comprises the spatial segregation of the epiblast (EPI) composed of pluripotent stem cells (PSCs) - also known as embryonic stem cells (ESCs) and the hypoblast composed of primitive endoderm (PrE) cells, allocating PrE cells between the EPI and blastocoel (Yamanaka et al. 2010, Leung \& Zernicka-Goetz 2015). All the three cell types of the pre-implantation blastocyst have different developmental destinations. In the conceptus, the EPI cells will originate the fetus, while the PrE will form the yolk sac, and the TE cells will contribute to the placenta (Schrode et al. 2013, Leung \& Zernicka-Goetz 2015).

In the mouse homozygous mutations for mTOR are lethal, and blastocysts fail to develop, displaying proliferation flaws of both embryonic and extraembryonic tissues (Murakami et al. 2004). Moreover, proliferation of both ICM and trophectoderm cells from these embryos was impaired in vitro, which was also observed in mutants lacking amino acid residues on the mTOR C terminus, critical for its kinase activity (Murakami et al. 2004).

To better understand the role of the mTOR pathway in both embryo development and in ESCs, studies have targeted the specific binding partners and upstream regulators of mTOR complexes. Thus, the lack of PI3K or Akt family members or subunits, both upstream regulators of mTOR activity, resulted in lethality or developmental defects (Peng et al. 2003, Tschopp et al. 2005, Yang et al. 2005, Foukas et al. 2006, Zhou et al. 2011, Yoshioka et al. 2012). Mutants of the direct regulators of mTORC1, TsC1 (Kobayashi et al. 2001), TsC2 (Rennebeck et al. 1998) and Rheb (Goorden et al. 2011) died approximately at the same developmental time window, with ectodermal and mesodermal lineage development defects. Interestingly, mutants of Raptor (mTORC1) become non-viable at the same developmental time as that of mTOR mutants, while Rictor (mTORC2) mutants die later due to fetal cardiovascular and nervous system abnormalities (Guertin et al. 2006, Shiota et al. 2006), indicating that each complex is involved in different developmental processes.

mTOR was also identified as a master regulator of embryonic diapause (ED - Box 1; Bulut-Karslioglu et al. 2016). In fact, culturing embryos in the presence of a pharmacological mTOR inhibitor arrested embryo development for 9-12 days at the blastocyst stage, an effect that was reversible upon the inhibitor removal. Moreover, this work was extended to PSCs, inducing a novel state of paused pluripotency in which cells presented a hypotranscriptome, proliferating less in 


\section{Box 1: Embryonic Diapause}

Diapause is a very conserved phenomenon across nature, from plants to mammals (MacRae 2010), though it does not happen equally in all living systems. ED is achieved when embryo development is very slow or even temporarily arrested (Fenelon \& Renfree 2018). Two forms of ED are currently known: obligatory or facultative. Obligatory diapause is species-specific and happens at a well-defined stage of development or in response to environmental stimuli such as photoperiod (Renfree \& Fenelon 2017). It occurs in some bats, bears and marsupials (Fenelon et al. 2014). Facultative diapause is a consequence of adverse conditions such as lactation or metabolic stress (e.g. starvation), when further embryo development could be risky (Lopes et al. 2004). This seems to be a very sophisticated mechanism to ensure that proper conditions for development to occur are available, optimizing offspring survival.

Facultative ED is frequent in some mammals such as mice. The hormonal regulation during lactation makes the uterus a hostile environment for implantation (Renfree \& Fenelon 2017); however because female mice can mate instantaneously after giving birth, ED is a strategic mechanism to guarantee the survival of the next generation without jeopardizing the current litter. Consequently, embryos develop until the blastocyst stage, and when there is contact with the uterine wall (apposition), they become dormant. During ED the rate of proliferation and growth becomes slower, accompanied by a decrease in DNA, RNA and protein synthesis. Furthermore, a hypometabolic state and an improvement of stress resistance are established (MacRae 2010, Fenelon et al. 2014). As soon as the proper conditions arise or upon estrogen administration, development is resumed and embryo implantation quickly takes place (Renfree \& Fenelon 2017). Thus, communication between the embryo and the uterine tissue appears to be critical in regulating diapause (Nichols et al. 2001, Fenelon et al. 2014).

The role of ovarian hormones on endometrial receptivity is clear, given that embryos from ovariectomized mice cannot implant and that estrogen and progesterone are important for uterine receptivity (Chen et al. 2000). Furthermore, estrogen is also essential for uterine LIF expression, which, in turn, is fundamental for implantation (Stewart et al. 1992, Chen et al. 2000). Female LIF-deficient mice generate viable embryos that cannot implant unless they are transferred to a pseudo-pregnant recipient (Stewart et al. 1992), and diapause embryos lacking part of the LIF receptor heterodimer are unable of develop (Nichols et al. 2001) demonstrating the importance of LIF in this process.

the presence of the inhibitor. The pausing effects were reversible without any negative impact on pluripotency. Earlier the same year the myelocytomatosis oncogene $(\mathrm{Myc})$ had already been suggested as a central player promoting ED, since transcriptional factor family members are under-expressed in paused embryos and $\mathrm{KO}$ or pharmacological inhibition of Myc members in mouse embryos, and mESCs also lead to a reversible diapause-like state in both pluripotent cells and embryos (Scognamiglio et al. 2016). However, this stage was sustained for only a few hours in culture, pinpointing that an upstream signal would be a best candidate to control developmental pausing, which is plausible given that Myc acts downstream of mTOR (Masui et al. 2013).

Considering the high plasticity of the embryo, the mTOR pathway may be somewhat redundant, and compensatory mechanisms could assure viability until the embryo develops to the blastocyst stage, where mTOR activity is, in fact, crucial for further development. Considering that the $\mathrm{KO}$ of mTOR regulators and binding partners display different embryonic phenotypes, it is not clear if the role of mTOR at this level is solely dependent on its kinase activity, as suggested by Murakami et al. (2004), or if it regulates cellular processes during earlier embryonic events that may be required for further blastocyst development (e.g. epigenetic alterations).

\section{mTOR and pluripotency regulation}

Pluripotency is a transient state during embryo development, but different pluripotent states can be recapitulated in vitro with defined media formulations (Nichols \& Smith 2012, De Los Angeles et al. 2015, Weinberger et al. 2016), allowing for the study of pluripotency regulation in vitro and comparisons to in vivo counterparts (Box 2). Changes in pluripotency and cell fate commitment involve not only metabolic and chromatin remodeling (Boroviak et al. 2014, Zylicz et al. 2015, Mathieu \& Ruohola-Baker 2017) but also signaling pathways (Illich et al. 2016, Weinberger et al. 2016).

Serum/LIF cultured PSCs represent a transient state between the naive and the primed state, since cells in this culture system are highly heterogeneous. Although the core pluripotency transcription factors are expressed, genes involved in naive cell self-renewal are heterogeneously expressed in serum/LIF cells (Chambers et al. 2007, Niwa et al. 2009), becoming more vulnerable to differentiation. Yet cells that downregulate these genes also seem to be able to re-express them (Chambers et al. 2007) and therefore are not completely committed.

Pluripotent mouse embryonic stem cells (mESC) were derived from the ICM of diapause blastocysts and cultured in vitro for the first time in 1981 (Evans \& Kaufman 1981, Martin 1981). These cells share many features with the epiblast (EPI) cells of the pre-implantation embryo (Boroviak et al. 2014), and they were later tagged as "naive" PSCs. There is another pluripotent state, described as the "primed" state, involving mEpiSCs, which resemble the post-implantation EPI cells of the embryo from where they were derived (Brons et al. 2007, Tesar et al. 2007, Nichols \& Smith 2012, Boroviak et al. 2014).

Stem cells can undergo an undefined number of divisions in culture, always maintaining the stem cell pool (self-renewal) without losing their ability to differentiate into specific lineages according to their potential (De Los Angeles et al. 2015). PSCs can differentiate into cells from the three germ layers, and this potential can be assessed using teratoma and chimera generation assays, which in theory should give rise to characteristic mesoderm, endoderm and ectoderm cell types 


\section{Box 2: Pluripotency Regulation}

Naive mESCs resemble ICM cells and express Oct4, Sox2 and Nanog, which are core pluripotency establishment and maintenance genes, acting through positive-feedback loops that promote their own expression and suppressing the expression of genes that trigger differentiation (Young 2011).

Other genes such as Klf4, Klf2, Esrrb, Tfcp2/1, Tbx3 and Gbx2 are involved in self-renewal and naive pluripotency preservation (Tai \& Ying 2013, Boroviak et al. 2014, Weinberger et al. 2016), and in some cases their expression is promoted by LIF signaling (Niwa et al. 2009, Tai \& Ying 2013, Martello et al. 2013, Ye et al. 2013) and the activity of the GSK3B inhibitor CHIR (also known as CHIR99021) (Wray et al. 2011, Martello et al. 2012). Moreover, using PD03, a MAPK/Erk inhibitor also enhances naive state propagation avoiding Erk-mediated chromatin modulation to promote the transcription of lineage-commitment genes (Tee et al. 2014).

mESC culture conditions have been improving throughout the years with the development of a medium supplemented with LIF and the two specific inhibitors noted earlier. This $2 \mathrm{i}$ media is sufficient to maintain naive pluripotency and self-renewal. Even though LIF signaling is dispensable for naive cell maintenance, its presence is beneficial for proliferation (Ying et al. 2008). On the other hand, mEpiSCs downregulate the expression of many of the genes from the pluripotency circuitry controlling naive cells pluripotency, such as Gbx2, Tbx3, Esrrb, Rex1 (Weinberger et al. 2016), while maintaining the expression of Oct4 and Sox2 (Tesar et al. 2007, Guo et al. 2009). At the same time, primed cells heterogeneously upregulate the expression of lineage-commitment genes, such as T-brachyury and Fgf5 (Tesar et al. 2007, Guo et al. 2009). Naive and primed cells differ not only in their developmental origin. EpiSCs, as mentioned, can be derived from the postimplantation embryo and can also be obtained by the differentiation of mESC by culturing cells in the presence of Fgf2/Activin A (Guo et al. 2009, Weinberger et al. 2016). Interestingly, mEpiSCs can differentiate into cells of the three germ layers in embryonic bodies and teratoma assays but inefficiently contribute toward chimeras (Brons et al. 2007) when injected in the ICM of pre-implantation embryos, probably due to their developmental incompatibility with the ICM of the pre-implantation embryo.

(Bradley et al. 1984, Huang et al. 2012, De Los Angeles et al. 2015).

In vivo the mTOR pathway is known to be involved in suppressing mesendoderm commitment (McLean et al. 2007, Zhou et al. 2009, Yu et al. 2015, Jung et al. 2016). While mTORC1 disruption appears to trigger early differentiation, mTORC2 seems to be important during later stages, rather than in early lineage priming (Zhao et al. 2014, Lu et al. 2017, Zheng et al. 2017a,b). mTOR activity has also been reported to enhance ectoderm differentiation (Freund et al. 2008, Jung et al. 2016), which could possibly be a consequence of preventing cell differentiation toward other germ layers.

In cultured ESCs mTOR has been associated with selfrenewal and pluripotency maintenance while preventing differentiation (Zhou et al. 2009, Ryu and Han 2011, Betschinger et al. 2013, Cho et al. 2014, Jung et al. 2016). In accordance, rapamycin, which targets mTORC1, can disrupt pluripotency by increasing differentiation rates in mesoderm/endoderm through a transient suppression of this complex (Zhou et al. 2009, Lu et al. 2017). However, this effect may not be solely mediated by mTORC1, given that prolonged exposure to rapamycin also disrupts mTORC2 (Sarbassov et al. 2006), raising the question of which mTOR complex plays the more crucial role in pluripotency. In contrast, other reports show that phosphorylated levels of S6K1 (a direct target of mTORC1) are reduced in hESCs when compared to differentiated cells (Easley et al. 2010), as are overall translation rates (Sampath et al. 2008, Easley et al. 2010). This may be closely associated with the balance between pluripotency and the translation of differentiation factors. Moreover, the mTOR-driven increase of S6K1 activity induces differentiation (Easley et al. 2010) and transient suppression of mTORC1 activity, with rapamycin enhancing the efficiency of pluripotency induction (Wang et al. 2013), indicating that mTORC1 inhibition favors both pluripotency maintenance and induction. Furthermore, the expression of DEPTOR, an intrinsically negative regulator of both $\mathrm{mTORC} 1$ and $\mathrm{mTORC} 2$, is increased in ESCs and downregulated during differentiation (Agrawal et al. 2014), modulating pluripotency by stabilizing Oct4, Nanog and Zfp42 expression.

mTOR activity has also been linked to glucose metabolism regulation downstream of LIN28, facilitating the transition from a naive to a primed pluripotency state by supporting high glycolysis flux and nucleotide metabolism (Zhang et al. 2016). Studies using other cell types revealed that mTORC1 is involved in the regulation of nucleotide synthesis (Düvel et al. 2010, Ben-Sahra et al. 2016) by controlling the expression of pentose phosphate pathway-related genes (Düvel et al. 2010) and glycolysis-related gene expression mediated by HIF1A (Li et al. 2014, Saxton \& Sabatini 2017). In cancer cells, mTORC2 indirectly regulates c-MYC availability by promoting its mRNA translation (Masui et al. 2013) and c-MYC is a well-known key regulator, not only of metabolic reprogramming of cancer cells but also of PSC metabolism. Likewise, AKT activation in a mTORC2-dependent fashion can also modulate glucose metabolism (Deprez et al. 1997, Hagiwara et al. 2012, Roberts et al. 2013, Masui et al. 2014), thus linking energy metabolism to biosynthetic processes relevant for differentiation. Considering the metabolic resemblance between PSCs and cancer cells, it would be interesting to determine the relevance of mTOR in the regulation of the metabolic pathways relevant in PSC identity. However, although there is some literature on mTOR and pluripotency, the findings are inconsistent and mechanisms involved in regulating the expression of the pluripotency or differentiation-related networks are poorly understood. 


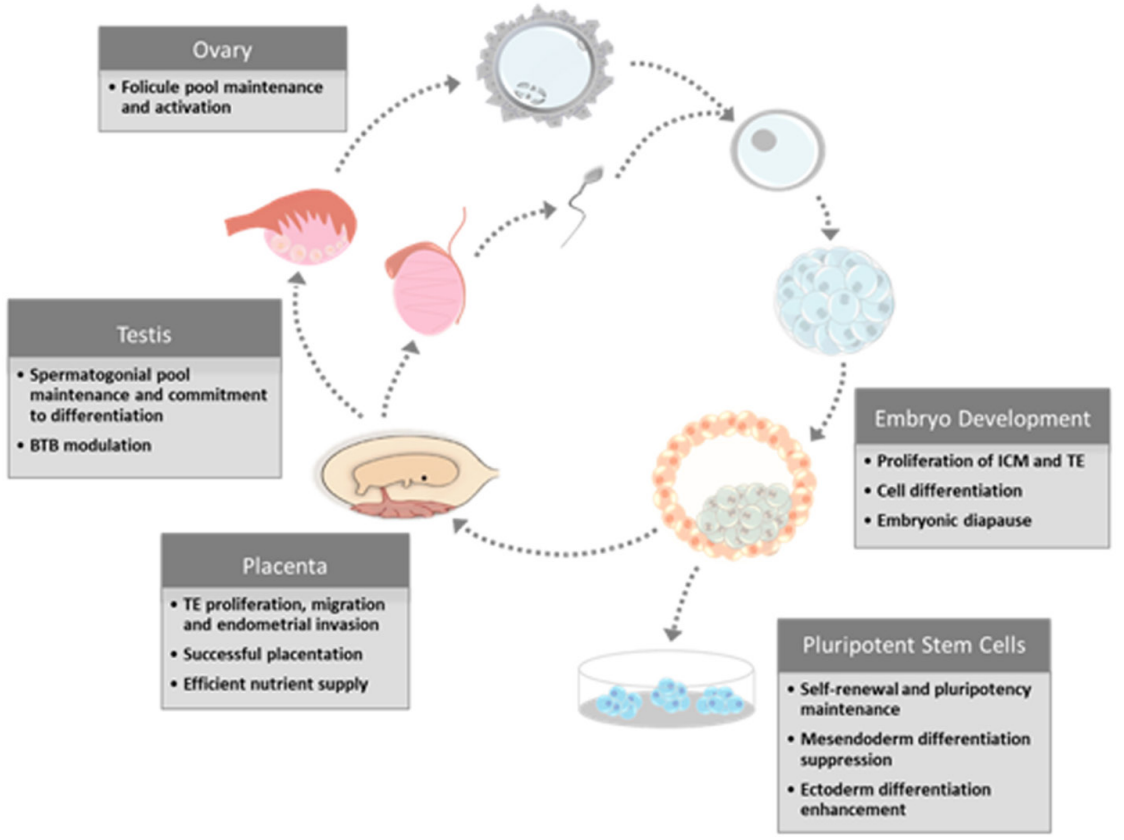

Figure $3 \mathrm{mTOR}$ in the reproductive cycle. The impact of the mTOR pathway on gamete production, embryo and placenta development and pluripotent stem cell maintenance and differentiation.

\section{mTOR and placenta establishment and function}

The importance of nutrients such as amino acids, as well as oxygen, on embryo metabolism and redox state is clear. By promoting survival and morphological changes, adaptation to stress, regulating epigenetic and transcriptional events, signaling and biosynthetic pathways, these nutrients are able to modulate development potential (Bazer et al. 2015, Eckert et al. 2015, Gardner \& Harvey 2015, Puscheck et al. 2015). Notably maternal metabolic status has a relevant role in supporting initial embryogenesis and implantation and may even affect fetal development and postnatal life (Bazer et al. 2015, Eckert et al. 2015, Puscheck et al. 2015).

In the majority of mammalian species, including rodents, ovine and porcine species, the attachment of blastocysts to the uterine luminal epithelium triggers mural TE cell differentiation into primary TE giant cells (TGCs), which in turn are able to invade the maternal tissue to reach the endometrial stroma, initiating placentation. mTOR has been shown to regulate trophectoderm cell outgrowth in the conceptuses (the embryonic/fetal and extraembryonic tissues) of these species in an amino acid- and glucose-dependent manner (Gwatkin 1966, Murakami et al. 2004, Bazer et al. 2012, González et al. 2012, Kim et al. 2013, Zeng et al. 2013, Wang et al. 2015), as well as cell migration (Correia-Branco et al. 2018) and metabolic gene expression (Rosario et al. 2019). In line with these observations, TE proliferation and migration are blocked by rapamycin in vitro (Murakami et al. 2004, González et al. 2012, Correia-Branco et al. 2018), and endometrial invasion is consequently decreased (Knuth et al. 2015). Given that amino acids are sensed by mTORC1 (Hara et al. 1998) and that rapamycin targets this complex, these studies suggest not only the prevailing role of mTORC1 rather than mTORC2 in TE cells but also that this pathway may act as an early checkpoint for development progression and successful implantation. In fact, Rictor ablation in mouse embryos results in abnormal placental histology, with smaller and thinner placentas that have an increased number of trophoblast giant cells with anomalous distribution and fewer maternal-fetal interfaces (Shiota et al. 2006).

Throughout the implantation process, endometrial nutrient supply is crucial for mTOR activity, together with TE cell crosstalk. Importantly, the availability of glucose, amino acids, fatty acids and other nutrients such as folate increases mTOR activity (Roos et al. 2009, Jansson et al. 2012, Lager et al. 2014, Rosario et al. 2017a,b), coupling the expression of placental nutrient transporters as well as their trafficking into the plasma membrane, which is also mTOR dependent (Roos et al. 2009, Rosario et al. 2011, 2013, 2016, Chen et al. 2015b). The physical link between embryonic and maternal tissues is essential to support further development events, given that the placenta is a dynamic organ and an exchange mediator between the mother and the fetus (Burton \& Jauniaux 2018). Low-protein diets and caloric restriction in pregnant females result in depressed placental levels of mTOR activation, affecting nutrient transport (Rosario et al. 2011, Kavitha et al. 2014). Furthermore, placental dysfunctions, fetal growth restriction and preeclampsia can result from aberrant TE invasion and are characterized by placental insufficiency and decreased mTOR activity (Roos et al. 2007, Yung et al. 2008, Arroyo et al. 2009, Chen et al. 2015b, Rosario et al. 2017b), increased autophagy (Zhang et al. 2017b) 
and altered nutrient availability, including amino acid transport (Vaughan et al. 2017). On the other hand, the placentas of both obese and diabetes mellitus-affected mothers have increased mTOR activation (Gaccioli et al. 2013, Jansson et al. 2013, Capobianco et al. 2016, Villalobos-Labra et al. 2017), which is related to the increased expression and abnormal function of nutrient transporters (Gaccioli et al. 2013, Lager et al. 2014). These effects culminate in fetal overgrowth, which is typical of animal models for obesity. These conditions jeopardize fetal development and are often associated with higher mobility and mortality (Wadhwa et al. 2009, Johnsson et al. 2015). However, there are unique biochemical and morphology characteristics across placental mammals (Roberts et al. 2016), and defining a good animal model for human placental-associated pathologies is difficult. Moreover, most of the human studies are performed on term or spontaneous preterm labor placentas, but considering that it is a highly dynamic organ throughout the gestation period, some of the effects of maternal metabolic dysfunctions on mTOR status and the coupled outcomes are hard to study in vivo or to accurately capture using in vitro models.

\section{Conclusion and future perspectives}

Published literature strongly supports an important role for mTOR function, involving both mTORC1 and mTORC2, in reproductive function, preserving the necessary homeostasis for adjusted gamete production and regulating the stem cell and follicle pool, essential for sperm and oocyte production. It is also important in embryo and placenta development, as well as in PSC maintenance and differentiation (Fig. 3). However, much work is needed to uncover the specific mTOR contributions, but, as discussed here, the key aspects are related to the control of metabolic quiescence and biosynthesis. Given the role of mTOR in energy sensing and nutrient availability, future work on this key pathway could include several parallel perspectives. On the one hand, if disruption of mTOR signaling could result in subfertility, via both quiescence of the stem cell pool and its premature exhaustion, mTOR manipulation might be useful in ovarian and pre-pubertal testicular tissue preservation in oncofertility procedures, avoiding stem cell loss. This could also be extended to both embryo culture and manipulation if diapause can be pharmacologically induced in human embryos, and to control placental development to both ensure implantation and avoid overgrowth in specific cases. Finally, mTOR could also be relevant in manipulating PSC fate, with possible implications for modifications and differentiation toward specific fates.

\section{Declaration of interest}

The authors declare that there is no conflict of interest that could be perceived as prejudicing the impartiality of this review.

\section{Funding}

This work was supported by Fundação para a Ciência e Tecnologia (FCT) Portugal, for PhD scholarship attributed to MIS (SFRH/BD/86260/2012). Funding was also provided by the STEM@REST Project (CENTRO-01-0145-FEDER-028871). We further acknowledge additional funding by the European Regional Development Fund (ERDF), through the Centro 2020 Regional Operational Programme: project CENTRO-010145-FEDER-000012-HealthyAging2020, the COMPETE 2020 - Operational Programme for Competitiveness and Internationalisation and the Portuguese national funds via FCT - Fundação para a Ciência e a Tecnologia, I.P.: project POCI01-0145-FEDER-007440.

\section{Author contribution statement}

BC and JRS developed the original idea. BC and MIS performed literature search and analysis and provided figures. BC wrote the main version of the manuscript, revised by JRS. All authors approved the final manuscript.

\section{Acknowledgements}

The authors would like to thank the members of the Biology of Reproduction and Stem Cells research group, at the Center from Neuroscience and Cell Biology, especially Ana Sofia Rodrigues, for many discussions and constructive feedback related to this work. We would also like to thank J Saints for informal language-related suggestions.

\section{References}

Adhikari D, Flohr G, Gorre N, Shen Y, Yang H, Lundin E, Lan Z, Gambello MJ \& Liu K 2009 Disruption of Tsc2 in oocytes leads to overactivation of the entire pool of primordial follicles. Molecular Human Reproduction 15 765-770. (https://doi.org/10.1093/molehr/gap092)

Adhikari D, Zheng W, Shen Y, Gorre N, Hamalainen T, Cooney AJ, Huhtaniemi I, Lan Z-J \& Liu K 2010 Tsc/mTORC1 signaling in oocytes governs the quiescence and activation of primordial follicles. Human Molecular Genetics 19 397-410. (https://doi.org/10.1093/hmg/ddp483)

Adhikari D, Risal S, Liu K \& Shen Y 2013 Pharmacological inhibition of mTORC1 prevents over-activation of the primordial follicle pool in response to elevated PI3K signaling. PLOS ONE 8 e53810. (https://doi. org/10.1371/journal.pone.0053810)

Agrawal P, Reynolds J, Chew S, Lamba DA \& Hughes RE 2014 DEPTOR is a stemness factor that regulates pluripotency of embryonic stem cells. Journal of Biological Chemistry 289 31818-31826. (https://doi. org/10.1074/jbc.M114.565838)

Arroyo JA, Brown LD \& Galan HL 2009 Placental mammalian target of rapamycin and related signaling pathways in an ovine model of intrauterine growth restriction. American Journal of Obstetrics and Gynecology 201 616.e1-616.e7. (https://doi.org/10.1016/j.ajog.2009.07.031)

Avilion AA, Nicolis SK, Pevny LH, Perez L, Vivian N \& Lovell-Badge $R$ 2003 Multipotent cell lineages in early mouse development depend on SOX2 function. Genes and Development 17 126-140. (https://doi. org/10.1101/gad.224503)

Bai S, Cheng L, Zhang Y, Zhu C, Zhu Z, Zhu R, Cheng CY, Ye L \& Zheng K 2018 A germline-specific role for the mTORC2 component rictor in maintaining spermatogonial differentiation and intercellular adhesion in mouse testis. MHR: Basic Science of Reproductive Medicine 24 244-259. (https://doi.org/10.1093/molehr/gay009)

Bazer FW, Song G, Kim J, Erikson DW, Johnson GA, Burghardt RC, Gao H, Carey Satterfield M, Spencer TE \& Wu G 2012 Mechanistic 
mammalian target of rapamycin (MTOR) cell signaling: effects of select nutrients and secreted phosphoprotein 1 on development of mammalian conceptuses. Molecular and Cellular Endocrinology 354 22-33. (https:// doi.org/10.1016/j.mce.2011.08.026)

Bazer FW, Johnson GA \& Wu G 2015 Amino acids and conceptus development during the peri-implantation period of pregnancy. Advances in Experimental Medicine and Biology 843 23-52. (https://doi. org/10.1007/978-1-4939-2480-6_2)

Bedzhov I, Graham SJL, Leung CY \& Zernicka-Goetz M 2014 Developmental plasticity, cell fate specification and morphogenesis in the early mouse embryo. Philosophical Transactions of the Royal Society B 369 20130538. (https://doi.org/10.1098/rstb.2013.0538)

Ben-Sahra I, Hoxhaj G, Ricoult SJH, Asara JM \& Manning BD 2016 mTORC1 induces purine synthesis through control of the mitochondrial tetrahydrofolate cycle. Science 351 728-733. (https://doi.org/10.1126/ science.aad0489)

Bererhi L, Flamant M, Martinez F, Karras A, Thervet E \& Legendre C 2003 Rapamycin-induced oligospermia. Transplantation 76 884-885.

Betschinger J, Nichols J, Dietmann S, Corrin PD, Paddison PJ \& Smith A 2013 Exit from pluripotency is gated by intracellular redistribution of the bHLH transcription factor Tfe3. Cell 153 335-347. (https://doi. org/10.1016/j.cell.2013.03.012)

Betz C, Stracka D, Prescianotto-Baschong C, Frieden M, Demaurex N \& Hall MN 2013 mTOR complex 2-Akt signaling at mitochondriaassociated endoplasmic reticulum membranes (MAM) regulates mitochondrial physiology. PNAS 110 12526-12534. (https://doi. org/10.1073/pnas.1302455110)

Boehmer C, Okur F, Setiawan I, Bröer S \& Lang F 2003 Properties and regulation of glutamine transporter SN1 by protein kinases SGK and PKB. Biochemical and Biophysical Research Communications 306 156-162. (https://doi.org/10.1016/S0006-291X(03)00921-5)

Boobes Y, Bernieh B, Saadi H, Hakim MRAI \& Abouchacra S 2010 Gonadal dysfunction and infertility in kidney transplant patients receiving sirolimus. International Urology and Nephrology 42 493-498. (https:// doi.org/10.1007/s11255-009-9644-8)

Boroviak T, Loos R, Bertone P, Smith A \& Nichols J 2014 The ability of inner-cell-mass cells to self-renew as embryonic stem cells is acquired following epiblast specification. Nature Cell Biology 16 513-525. (https://doi.org/10.1038/ncb2965)

Boyer A, Girard M, Thimmanahalli DS, Levasseur A, Celeste C, Paquet M, Duggavathi R \& Boerboom D 2016 mTOR regulates gap junction Alpha-1 protein trafficking in Sertoli cells and is required for the maintenance of spermatogenesis in mice. Biology of Reproduction 95 13-13. (https:// doi.org/10.1095/biolreprod.115.138016)

Bradley A, Evans M, Kaufman MH \& Robertson E 1984 Formation of germline chimaeras from embryo-derived teratocarcinoma cell lines. Nature 309 255-256. (https://doi.org/10.1038/309255a0)

Brons IGM, Smithers LE, Trotter MWB, Rugg-Gunn P, Sun B, Chuva de Sousa Lopes SM, Howlett SK, Clarkson A, Ahrlund-Richter L, Pedersen RA et al. 2007 Derivation of pluripotent epiblast stem cells from mammalian embryos. Nature 448 191-195. (https://doi.org/10.1038/nature05950)

Brown EJ, Albers MW, Bum Shin T, ichikawa K, Keith CT, Lane WS \& Schreiber SL 1994 A mammalian protein targeted by G1-arresting rapamycin-receptor complex. Nature 369 756-758. (https://doi. org/10.1038/369756a0)

Brugarolas JB, Vazquez F, Reddy A, Sellers WR \& Kaelin WG 2003 TSC2 regulates VEGF through mTOR-dependent and -independent pathways. Cancer Cell 4 147-158. (https://doi.org/10.1016/S15356108(03)00187-9)

Brugarolas J, Lei K, Hurley RL, Manning BD, Reiling JH, Hafen E, Witters LA, Ellisen LW \& Kaelin WG 2004 Regulation of mTOR function in response to hypoxia by REDD1 and the TSC1/TSC2 tumor suppressor complex. Genes and Development 18 2893-2904. (https:// doi.org/10.1101/gad.1256804)

Bulut-Karslioglu A, Biechele S, Jin H, Macrae TA, Hejna M, Gertsenstein M, Song JS \& Ramalho-Santos M 2016 Inhibition of mTOR induces a paused pluripotent state. Nature $\mathbf{5 4 0}$ 119-123. (https://doi.org/10.1038/ nature20578)

Burton GJ \& Jauniaux E 2018 Pathophysiology of placental-derived fetal growth restriction. American Journal of Obstetrics and Gynecology 218 S745-S761. (https://doi.org/10.1016/j.ajog.2017.11.577)

Busada JT, Chappell VA, Niedenberger BA, Kaye EP, Keiper BD, Hogarth CA \& Geyer CB 2015 Retinoic acid regulates Kit translation during spermatogonial differentiation in the mouse. Developmental Biology 397 140-149. (https://doi.org/10.1016/j.ydbio.2014.10.020)

Capobianco E, Fornes D, Linenberg I, Powell TL, Jansson T \& Jawerbaum A 2016 A novel rat model of gestational diabetes induced by intrauterine programming is associated with alterations in placental signaling and fetal overgrowth. Molecular and Cellular Endocrinology 422 221-232. (https://doi.org/10.1016/j.mce.2015.12.020)

Chambers I, Colby D, Robertson M, Nichols J, Lee S, Tweedie S \& Smith A 2003 Functional expression cloning of Nanog, a pluripotency sustaining factor in embryonic stem cells. Cell 113 643-655. (https://doi. org/10.1016/S0092-8674(03)00392-1)

Chambers I, Silva J, Colby D, Nichols J, Nijmeijer B, Robertson M, Vrana J, Jones K, Grotewold L \& Smith A 2007 Nanog safeguards pluripotency and mediates germline development. Nature 450 1230-1234. (https:// doi.org/10.1038/nature06403)

Chatterjee A, Mukhopadhyay S, Tung K, Patel D \& Foster DA 2015 Rapamycininduced G1 cell cycle arrest employs both TGF- $\beta$ and Rb pathways. Cancer Letters 360 134-140. (https://doi.org/10.1016/j.canlet.2015.01.043)

Chen J, Torcia S, Xie F, Lin C-J, Cakmak H, Franciosi F, Horner K, Onodera C, Song JS, Cedars MI et al. 2013 Somatic cells regulate maternal mRNA translation and developmental competence of mouse oocytes. Nature Cell Biology 15 1415-1423. (https://doi.org/10.1038/ncb2873)

Chen Z, Kang X, Wang L, Dong H, Wang C, Xiong Z, Zhao W, Jia C, Lin J, Zhang W et al. 2015a Rictor/mTORC2 pathway in oocytes regulates folliculogenesis, and its inactivation causes premature ovarian failure. Journal of Biological Chemistry 290 6387-6396. (https://doi.org/10.1074/ jbc.M114.605261)

Chen Y-Y, Rosario FJ, Shehab MA, Powell TL, Gupta MB \& Jansson T 2015b Increased ubiquitination and reduced plasma membrane trafficking of placental amino acid transporter SNAT-2 in human IUGR. Clinical Science 129 1131-1141. (https://doi.org/10.1042/CS20150511)

Cheng CY \& Mruk DD 2012 The blood-testis barrier and its implications for male contraception. Pharmacological Reviews 64 16-64. (https://doi. org/10.1124/pr.110.002790)

Cheng Y, Kim J, Li XX \& Hsueh AJ 2015 Promotion of ovarian follicle growth following mTOR activation: synergistic effects of AKT stimulators. PLoS ONE 10 e0117769. (https://doi.org/10.1371/journal.pone.0117769)

Cho Y-H, Han K-M, Kim D, Lee J, Lee S-H, Choi K-W, Kim J \& Han YM 2014 Autophagy regulates homeostasis of pluripotency-associated proteins in hESCs. Stem Cells 32 424-435. (https://doi.org/10.1002/ stem.1589)

Choi J, Jo M, Lee E \& Choi D 2014 AKT is involved in granulosa cell autophagy regulation via mTOR signaling during rat follicular development and atresia. Reproduction 147 73-80. (https://doi.org/10.1530/REP-13-0386)

Correia-Branco A, Keating E \& Martel F 2018 Involvement of mTOR, JNK and PI3K in the negative effect of ethanol and metformin on the human first-trimester extravillous trophoblast HTR-8/SVneo cell line. European Journal of Pharmacology 833 16-24. (https://doi.org/10.1016/j. ejphar.2018.05.038)

Cunningham JT, Rodgers JT, Arlow DH, Vazquez F, Mootha VK \& Puigserver P 2007 mTOR controls mitochondrial oxidative function through a YY1-PGC-1 $\alpha$ transcriptional complex. Nature 450 736-740. (https://doi.org/10.1038/nature06322)

De Los Angeles A, Ferrari F, Xi R, Fujiwara Y, Benvenisty N, Deng H, Hochedlinger K, Jaenisch R, Lee S, Leitch HG et al. 2015 Hallmarks of pluripotency. Nature $\mathbf{5 2 5}$ 469-478. (https://doi.org/10.1038/ nature15515)

Deprez J, Vertommen D, Alessi DR, Hue L \& Rider MH 1997 Phosphorylation and activation of heart 6-phosphofructo-2-kinase by protein kinase $B$ and other protein kinases of the insulin signaling cascades. Journal of Biological Chemistry 272 17269-17275. (https:// doi.org/10.1074/jbc.272.28.17269)

Deutsch MA, Kaczmarek I, Huber S, Schmauss D, Beiras-Fernandez A, Schmoeckel M, Ochsenkuehn R, Meiser B, Mueller-Hoecker J \& Bruno Reichart B 2007 Sirolimus-associated infertility: case report and literature review of possible mechanisms. American Journal of Transplantation 7 2414-2421. (https://doi.org/10.1111/j.1600-6143.2007.01929.x)

DeYoung MP, Horak P, Sofer A, Sgroi D \& Ellisen LW 2008 Hypoxia regulates TSC1/2-mTOR signaling and tumor suppression through REDD1-mediated 14-3-3 shuttling. Genes and Development 22 239-251. (https://doi.org/10.1101/gad.1617608)

Dong H, Chen Z, Wang C, Xiong Z, Zhao W, Jia C, Lin J, Lin Y, Yuan W, Zhao AZ et al. 2015 Rictor regulates spermatogenesis by controlling 
Sertoli cell cytoskeletal organization and cell polarity in the mouse testis. Endocrinology 156 4244-4256. (https://doi.org/10.1210/en.2015-1217)

Dou X, Sun Y, Li J, Zhang J, Hao D, Liu W, Wu R, Kong F, Peng X \& Li J 2017 Short-term rapamycin treatment increases ovarian lifespan in young and middle-aged female mice. Aging Cell 16 825-836. (https:// doi.org/10.1111/acel.12617)

Düvel K, Yecies JL, Menon S, Raman P, Lipovsky AI, Souza AL, Triantafellow E, Ma Q, Gorski R, Cleaver S et al. 2010 Activation of a metabolic gene regulatory network downstream of mTOR complex 1. Molecular Cell 39 171-183. (https://doi.org/10.1016/j. molcel.2010.06.022)

Easley CA, Ben-Yehudah A, Redinger CJ, Oliver SL, Varum ST, Eisinger VM, Carlisle DL, Donovan PJ \& Schatten GP 2010 mTOR-mediated activation of p70 S6K induces differentiation of pluripotent human embryonic stem cells. Cellular Reprogramming 12 263-273. (https://doi.org/10.1089/ cell.2010.0011)

Eckert J, Velazquez MA \& Fleming TP 2015 Cell signalling during blastocyst morphogenesis. Advances in Experimental Medicine and Biology 843 1-21. (https://doi.org/10.1007/978-1-4939-2480-6_1)

Evans MJ \& Kaufman MH 1981 Establishment in culture of pluripotential cells from mouse embryos. Nature 292 154-156. (https://doi. org/10.1038/292154a0)

Fenelon JC \& Renfree MB 2018 The history of the discovery of embryonic diapause in mammals. Biology of Reproduction 99 242-251. (https:// doi.org/10.1093/biolre/ioy112)

Fenelon JC, Banerjee A \& Murphy BD 2014 Embryonic diapause: development on hold. International Journal of Developmental Biology 58 163-174. (https://doi.org/10.1387/ijdb.140074bm)

Fierro-González JC, White MD, Silva JC \& Plachta N 2013 Cadherindependent filopodia control preimplantation embryo compaction. Nature Cell Biology 15 1424-1433. (https://doi.org/10.1038/ncb2875)

Fingar DC, Richardson CJ, Tee AR, Cheatham L, Tsou C \& Blenis J 2004 mTOR controls cell cycle progression through its cell growth effectors S6K1 and 4E-BP1/eukaryotic translation initiation factor 4E. Molecular and Cellular Biology 24 200-216. (https://doi.org/10.1128/ MCB.24.1.200-216.2004)

Foukas LC, Claret M, Pearce W, Okkenhaug K, Meek S, Peskett E, Sancho S, Smith AJH, Withers DJ \& Vanhaesebroeck B 2006 Critical role for the $\mathrm{p} 110 \alpha$ phosphoinositide-3-OH kinase in growth and metabolic regulation. Nature 441 366-370. (https://doi.org/10.1038/nature04694)

Freund C, Ward-van Oostwaard D, Monshouwer-Kloots J, van den Brink S, van Rooijen M, Xu X, Zweigerdt R, Mummery C \& Passier R 2008 Insulin redirects differentiation from cardiogenic mesoderm and endoderm to neuroectoderm in differentiating human embryonic stem cells. Stem Cells 26 724-733. (https://doi.org/10.1634/stemcells.2007-0617)

Fritsche L, Budde K, Dragun D, Einecke G, Diekmann F \& Neumayer HH 2004 Testosterone concentrations and sirolimus in male renal transplant patients. American Journal of Transplantation 4 130-131. (https://doi. org/10.1046/j.1600-6135.2003.00279.x)

Gaccioli F, White V, Capobianco E, Powell TL, Jawerbaum A \& Jansson T 2013 Maternal overweight induced by a diet with high content of saturated fat activates placental mTOR and elF2alpha signaling and increases fetal growth in rats1. Biology of Reproduction 89 96-91. (https://doi.org/10.1095/biolreprod.113.109702)

Gao N, Flynn DC, Zhang Z, Zhong X-S, Walker V, Liu KJ, Shi X \& Jiang BH 2004 G 1 cell cycle progression and the expression of G 1 cyclins are regulated by $\mathrm{PI} 3 \mathrm{~K} / \mathrm{AKT} / \mathrm{mTOR} / \mathrm{p} 70 \mathrm{S6} \mathrm{K} 1$ signaling in human ovarian cancer cells. American Journal of Physiology: Cell Physiology 287 C281C291. (https://doi.org/10.1152/ajpcell.00422.2003)

García-Martínez JM \& Alessi DR 2008 mTOR complex 2 (mTORC2) controls hydrophobic motif phosphorylation and activation of serumand glucocorticoid-induced protein kinase 1 (SGK1). Biochemical Journal 416 375-385. (https://doi.org/10.1042/BJ20081668)

Gardner DK \& Harvey AJ 2015 Blastocyst metabolism. Reproduction, Fertility and Development 27 638. (https://doi.org/10.1071/RD14421)

González IM, Martin PM, Burdsal C, Sloan JL, Mager S, Harris T \& Sutherland AE 2012 Leucine and arginine regulate trophoblast motility through mTOR-dependent and independent pathways in the preimplantation mouse embryo. Developmental Biology 361 286-300. (https://doi.org/10.1016/j.ydbio.2011.10.021)

Goolam M, Scialdone A, Graham SJL, Macaulay IC, Jedrusik A, Hupalowska A, Voet T, Marioni JC \& Zernicka-Goetz M 2016
Heterogeneity in Oct4 and Sox2 targets biases cell fate in 4-cell mouse embryos. Cell 165 61-74. (https://doi.org/10.1016/j. cell.2016.01.047)

Goorden SMI, Hoogeveen-Westerveld M, Cheng C, van Woerden GM, Mozaffari M, Post L, Duckers HJ, Nellist M \& Elgersma Y 2011 Rheb is essential for murine development. Molecular and Cellular Biology 31 1672-1678. (https://doi.org/10.1128/MCB.00985-10)

Guertin DA, Stevens DM, Thoreen CC, Burds AA, Kalaany NY, Moffat J, Brown M, Fitzgerald KJ \& Sabatini DM 2006 Ablation in mice of the mTORC components raptor, rictor, or $\mathrm{mLST} 8$ reveals that $\mathrm{mTORC} 2$ is required for signaling to Akt-FOXO and PKC $\alpha$, but not S6K1. Developmental Cell 11 859-871. (https://doi.org/10.1016/j.devcel.2006.10.007)

Guo G, Yang J, Nichols J, Hall JS, Eyres I, Mansfield W \& Smith A 2009 KIf4 reverts developmentally programmed restriction of ground state pluripotency. Development 136 1063-1069. (https://doi.org/10.1242/ dev.030957)

Guo J, Zhang T, Guo Y, Sun T, Li H, Zhang X, Yin H, Cao G, Yin Y, Wang H et al. 2018 Oocyte stage-specific effects of MTOR determine granulosa cell fate and oocyte quality in mice. PNAS 115 E5326-E5333. (https:// doi.org/10.1073/pnas.1800352115)

Gwatkin RBL 1966 Amino acid requirements for attachment and outgrowth of the mouse blastocystin vitro. Journal of Cellular Physiology $\mathbf{6 8}$ 335-343. (https://doi.org/10.1002/jcp.1040680313)

Hagiwara A, Cornu M, Cybulski N, Polak P, Betz C, Trapani F, Terracciano L, Heim MH, Rüegg MA \& Hall MN 2012 Hepatic mTORC2 activates glycolysis and lipogenesis through Akt, glucokinase, and SREBP1c. Cell Metabolism 15 725-738. (https://doi.org/10.1016/j. cmet.2012.03.015)

Hara K, Yonezawa K, Weng QP, Kozlowski MT, Belham C \& Avruch J 1998 Amino acid sufficiency and $m$ TOR regulate p70 S6 kinase and elF-4E BP1 through a common effector mechanism. Journal of Biological Chemistry 273 14484-14494. (https://doi.org/10.1074/jbc.273.23.14484)

Hardie DG, Ross FA \& Hawley SA 2012 AMPK: a nutrient and energy sensor that maintains energy homeostasis. Nature Reviews: Molecular Cell Biology 13 251-262. (https://doi.org/10.1038/nrm3311)

Heitman J, Movva NR \& Hall MN 1991 Targets for cell cycle arrest by the immunosuppressant rapamycin in yeast. Science 253 905-909. (https:// doi.org/10.1126/science.1715094)

Hirose K, Shiomi T, Hozumi S \& Kikuchi Y 2014 Mechanistic target of rapamycin complex 1 signaling regulates cell proliferation, cell survival, and differentiation in regenerating zebrafish fins. BMC Developmental Biology 14 42. (https://doi.org/10.1186/s12861-014-0042-9)

Hobbs RM, Seandel M, Falciatori I, Rafii S \& Pandolfi PP 2010 Plzf regulates germline progenitor self-renewal by opposing mTORC1. Cell 142 468-479. (https://doi.org/10.1016/j.cell.2010.06.041)

Hobbs RM, La HM, Makela J-A, Kobayashi T, Noda T \& Pandolfi PP 2015 Distinct germline progenitor subsets defined through Tsc2-mTORC1 signaling. EMBO Reports 16 467-480. (https://doi.org/10.15252/ embr.201439379)

Holstein A-F, Schulze W \& Davidoff M 2003 Understanding spermatogenesis is a prerequisite for treatment. Reproductive Biology and Endocrinology 1 1-107.

Huang Y, Osorno R, Tsakiridis A \& Wilson V 2012 In vivo differentiation potential of epiblast stem cells revealed by chimeric embryo formation. Cell Reports 2 1571-1578. (https://doi.org/10.1016/j.celrep.2012.10.022)

Illich DJ, Zhang M, Ursu A, Osorno R, Kim K-P, Yoon J, Araúzo-Bravo MJ, Wu G, Esch D, Sabour D et al. 2016 Distinct signaling requirements for the establishment of ESC pluripotency in late-stage EpiSCs. Cell Reports 15 787-800. (https://doi.org/10.1016/j.celrep.2016.03.073)

Inoki K, Li Y, Zhu T, Wu J \& Guan K-L 2002 TSC2 is phosphorylated and inhibited by Akt and suppresses mTOR signalling. Nature Cell Biology 4 648-657. (https://doi.org/10.1038/ncb839)

Inoki K, Zhu T \& Guan K-L 2003a TSC2 mediates cellular energy response to control cell growth and survival. Cell 115 577-590. (https://doi. org/10.1016/S0092-8674(03)00929-2)

Inoki K, Li Y, Xu T \& Guan K-L 2003b Rheb GTPase is a direct target of TSC2 GAP activity and regulates mTOR signaling. Genes and Development 17 1829-1834. (https://doi.org/10.1101/gad.1110003)

Jacinto E, Loewith R, Schmidt A, Lin S, Rüegg MA, Hall A \& Hall MN 2004 Mammalian TOR complex 2 controls the actin cytoskeleton and is rapamycin insensitive. Nature Cell Biology 6 1122-1128. (https://doi. org/10.1038/ncb1183) 
Jansson T, Aye ILMH \& Goberdhan DCI 2012 The emerging role of mTORC1 signaling in placental nutrient-sensing. Placenta 33 e23-e29. (https://doi.org/10.1016/j.placenta.2012.05.010)

Jansson N, Rosario FJ, Gaccioli F, Lager S, Jones HN, Roos S, Jansson T \& Powell TL 2013 Activation of placental mTOR signaling and amino acid transporters in obese women giving birth to large babies. Journal of Clinical Endocrinology and Metabolism 98 105-113. (https://doi. org/10.1210/jc.2012-2667)

Julien L-A, Carriere A, Moreau J \& Roux PP 2010 mTORC1-activated S6K1 phosphorylates rictor on threonine 1135 and regulates mTORC2 signaling. Molecular and Cellular Biology 30 908-921. (https://doi. org/10.1128/MCB.00601-09)

Jung J-H, Kang K-W, Kim J, Hong S-C, Park Y \& Kim BS 2016 CXCR2 inhibition in human pluripotent stem cells induces predominant differentiation to mesoderm and endoderm through repression of mTOR, $\beta$-catenin, and hTERT activities. Stem Cells and Development 25 1006-1019. (https://doi.org/10.1089/scd.2015.0395)

Kavitha JV, Rosario FJ, Nijland MJ, McDonald TJ, Wu G, Kanai Y, Powell TL, Nathanielsz PW \& Jansson T 2014 Down-regulation of placental mTOR, insulin/IGF-I signaling, and nutrient transporters in response to maternal nutrient restriction in the baboon. FASEB Journal 28 1294-1305. (https:// doi.org/10.1096/fj.13-242271)

Kayampilly PP \& Menon KMJ 2007 Follicle-stimulating hormone increases tuberin phosphorylation and mammalian target of rapamycin signaling through an extracellular signal-regulated kinase-dependent pathway in rat granulosa cells. Endocrinology 148 3950-3957. (https://doi. org/10.1210/en.2007-0202)

Kim JE \& Chen J 2004 regulation of peroxisome proliferator-activated receptor-gamma activity by mammalian target of rapamycin and amino acids in adipogenesis. Diabetes 53 2748-2756. (https://doi.org/10.2337/ diabetes.53.11.2748)

Kim D-H, Sarbassov DD, Ali SM, King JE, Latek RR, Erdjument-Bromage $H$, Tempst P \& Sabatini DM 2002 mTOR interacts with raptor to form a nutrient-sensitive complex that signals to the cell growth machinery. Cell 110 163-175. (https://doi.org/10.1016/S0092-8674(02)00808-5)

Kim E, Goraksha-Hicks P, Li L, Neufeld TP \& Guan K-L 2008 Regulation of TORC1 by Rag GTPases in nutrient response. Nature Cell Biology 10 935-945. (https://doi.org/10.1038/ncb1753)

Kim J, Song G, Wu G, Gao H, Johnson GA \& Bazer FW 2013 Arginine, leucine, and glutamine stimulate proliferation of porcine trophectoderm cells through the MTOR-RPS6K-RPS6-EIF4EBP1 signal transduction pathway. Biology of Reproduction 88113.

Knuth A, Liu L, Nielsen H, Merril D, Torry DS \& Arroyo JA 2015 Placenta growth factor induces invasion and activates p70 during rapamycin treatment in trophoblast cells. American Journal of Reproductive Immunology 73 330-340. (https://doi.org/10.1111/aji.12327)

Kobayashi T, Minowa O, Sugitani Y, Takai S, Mitani H, Kobayashi E, Noda T \& Hino O 2001 A germ-line Tsc1 mutation causes tumor development and embryonic lethality that are similar, but not identical to, those caused by Tsc2 mutation in mice. PNAS 98 8762-8767. (https://doi. org/10.1073/pnas.151033798)

Kogasaka Y, Hoshino Y, Hiradate Y, Tanemura K \& Sato E 2013 Distribution and association of mTOR with its cofactors, raptor and rictor, in cumulus cells and oocytes during meiotic maturation in mice. Molecular Reproduction and Development 80 334-348. (https://doi.org/10.1002/ $\operatorname{mrd}$.22166)

Koren I, Reem E \& Kimchi A 2010 DAP1, a novel substrate of mTOR, negatively regulates autophagy. Current Biology 20 1093-1098. (https:// doi.org/10.1016/j.cub.2010.04.041)

Lager S, Jansson T \& Powell TL 2014 Differential regulation of placental amino acid transport by saturated and unsaturated fatty acids. American Journal of Physiology: Cell Physiology 307 C738-C744. (https://doi. org/10.1152/ajpcell.00196.2014)

Laplante M \& Sabatini DM 2012 MTOR signaling in growth control and disease. Cel/ 149 274-293. (https://doi.org/10.1016/j.cell.2012.03.017)

Lee S, Coco M, Greenstein SM, Schechner RS, Tellis VA \& Glicklich DG 2005 The effect of sirolimus on sex hormone levels of male renal transplant recipients. Clinical Transplantation 19 162-167. (https://doi. org/10.1111/j.1399-0012.2005.00257.x)

Lee SE, Sun SC, Choi HY, Uhm SJ \& Kim NH 2012 mTOR is required for asymmetric division through small GTPases in mouse oocytes. Molecular Reproduction and Development 79 356-366. (https://doi.org/10.1002/ mrd.22035)
Leung CY \& Zernicka-Goetz M 2015 Mapping the journey from totipotency to lineage specification in the mouse embryo. Current Opinion in Genetics and Development 34 71-76. (https://doi.org/10.1016/j.gde.2015.08.002)

Li N \& Liu L 2018 Mechanism of resveratrol in improving ovarian function in a rat model of premature ovarian insufficiency. Journal of Obstetrics and Gynaecology Research 44 1431-1438. (https://doi.org/10.1111/jog.13680)

Li S, Ogawa W, Emi A, Hayashi K, Senga Y, Nomura K, Hara K, Yu D \& Kasuga M 2011 Role of S6K1 in regulation of SREBP1c expression in the liver. Biochemical and Biophysical Research Communications $\mathbf{4 1 2}$ 197-202. (https://doi.org/10.1016/j.bbrc.2011.07.038)

Li Z, Li X, Wu S, Xue M \& Chen W 2014 Long non-coding RNA UCA1 promotes glycolysis by upregulating hexokinase 2 through the mTORSTAT3/microRNA143 pathway. Cancer Science 105 951-955. (https:// doi.org/10.1111/cas.12461)

Liu P, Gan W, Inuzuka H, Lazorchak AS, Gao D, Arojo O, Liu D, Wan L, Zhai B, Yu Y et al. 2013 Sin1 phosphorylation impairs mTORC2 complex integrity and inhibits downstream Akt signalling to suppress tumorigenesis. Nature Cell Biology 15 1340-1350. (https://doi.org/10.1038/ncb2860)

Long X, Lin Y, Ortiz-Vega S, Yonezawa K \& Avruch J 2005 Rheb binds and regulates the mTOR kinase. Current Biology 15 702-713. (https://doi. org/10.1016/j.cub.2005.02.053)

Lopes FL, Desmarais JA \& Murphy BD 2004 Embryonic diapause and its regulation. Reproduction 128 669-678. (https://doi.org/10.1530/ rep.1.00444)

Lu Q, Liu Y, Wang Y, Wang W, Yang Z, Li T, Tian Y, Chen P, Ma K, Jia Z et al. 2017 Rapamycin efficiently promotes cardiac differentiation of mouse embryonic stem cells. Bioscience Reports 37 BSR20160552. (https://doi. org/10.1042/BSR20160552)

Luo L, Xu J \& Fu Y 2013 Rapamycin prolongs female reproductive lifespan. Cell Cycle 12 3353-3354. (https://doi.org/10.4161/cc.26578)

Ma XM \& Blenis J 2009 Molecular mechanisms of mTOR-mediated translational control. Nature Reviews: Molecular Cell Biology 10 307-318. (https://doi.org/10.1038/nrm2672)

MacRae TH 2010 Gene expression, metabolic regulation and stress tolerance during diapause. Cellular and Molecular Life Sciences 67 2405-2424. (https://doi.org/10.1007/s00018-010-0311-0)

Manning BD, Tee AR, Logsdon MN, Blenis J \& Cantley LC 2002 Identification of the tuberous sclerosis complex-2 tumor suppressor gene product tuberin as a target of the phosphoinositide 3-kinase/Akt pathway. Molecular Cell 10 151-162. (https://doi.org/10.1016/S10972765(02)00568-3)

Martello G, Sugimoto T, Diamanti E, Joshi A, Hannah R, Ohtsuka S, Göttgens B, Niwa H \& Smith A 2012 Esrrb is a pivotal target of the GSK3/Tcf3 axis regulating embryonic stem cell self-renewal. Cell Stem Cell 11 491-504. (https://doi.org/10.1016/j.stem.2012.06.008)

Martello G, Bertone P \& Smith A 2013 Identification of the missing pluripotency mediator downstream of leukaemia inhibitory factor. $E M B O$ Journal 32 2561-2574. (https://doi.org/10.1038/emboj.2013.177)

Martin GR 1981 Isolation of a pluripotent cell line from early mouse embryos cultured in medium conditioned by teratocarcinoma stem cells. PNAS 78 7634-7638. (https://doi.org/10.1073/pnas.78.12.7634)

Mascarenhas MN, Flaxman SR, Boerma T, Vanderpoel S \& Stevens GA 2012 National, regional, and global trends in infertility prevalence since 1990: a systematic analysis of 277 health surveys. PLoS Medicine 9 1-12. (https://doi.org/10.1371/journal.pmed.1001356)

Masui K, Tanaka K, Akhavan D, Babic I, Gini B, Matsutani T, Iwanami A, Liu F, Villa GR, Gu Y et al. 2013 mTOR complex 2 controls glycolytic metabolism in glioblastoma through FoxO acetylation and upregulation of c-Myc. Cell Metabolism 18 726-739. (https://doi.org/10.1016/j. cmet.2013.09.013)

Masui K, Cavenee WK \& Mischel PS 2014 mTORC2 in the center of cancer metabolic reprogramming. Trends in Endocrinology and Metabolism 25 364-373. (https://doi.org/10.1016/j.tem.2014.04.002)

Mathieu J \& Ruohola-Baker H 2017 Metabolic remodeling during the loss and acquisition of pluripotency. Development 144 541-551. (https://doi. org/10.1242/dev.128389)

McDole K, Xiong Y, Iglesias PA \& Zheng Y 2011 Lineage mapping the preimplantation mouse embryo by two-photon microscopy, new insights into the segregation of cell fates. Developmental Biology 355 239-249. (https://doi.org/10.1016/j.ydbio.2011.04.024)

McLean AB, D'Amour KA, Jones KL, Krishnamoorthy M, Kulik MJ, Reynolds DM, Sheppard AM, Liu H, Xu Y, Baetge EE et al. 2007 Activin A efficiently specifies definitive endoderm from human embryonic stem 
cells only when phosphatidylinositol 3-kinase signaling is suppressed. Stem Cells 25 29-38.

Mitsui K, Tokuzawa Y, Itoh H, Segawa K, Murakami M, Takahashi K, Maruyama M, Maeda M \& Yamanaka S 2003 The homeoprotein Nanog is required for maintenance of pluripotency in mouse epiblast and ES cells. Cell 113 631-642. (https://doi.org/10.1016/S0092-8674(03)00393-3)

Miyamoto T, Tsujimura A, Miyagawa Y, Koh E, Namiki M \& Sengoku K 2012 Male infertility and its causes in human. Advances in Urology 2012 1-7. (https://doi.org/10.1155/2012/384520)

Mok KW, Mruk DD, Silvestrini B \& Cheng CY 2012 rpS6 regulates bloodtestis barrier dynamics by affecting F-actin organization and protein recruitment. Endocrinology 153 5036-5048. (https://doi.org/10.1210/ en.2012-1665)

Mok KW, Mruk DD \& Yan Cheng CY 2013a Regulation of blood-testis barrier (BTB) dynamics during spermatogenesis via the 'Yin' and 'Yang' effects of mammalian target of rapamycin Complex 1 (mTORC1) and mTORC2. International Review of Cell and Molecular Biology 301 291-358. (https://doi.org/10.1016/B978-0-12-407704-1.00006-3)

Mok KW, Mruk DD, Lee WM \& Cheng CY 2013b Rictor/mTORC2 regulates blood-testis barrier dynamics via its effects on gap junction communications and actin filament network. FASEB Journal 27 1137-1152. (https://doi.org/10.1096/fj.12-212977)

Mok KW, Chen H, Lee WM \& Cheng CY 2015 RpS6 regulates bloodtestis barrier dynamics through Arp3-mediated actin microfilament organization in rat Sertoli cells. An in vitro study. Endocrinology 156 1900-1913. (https://doi.org/10.1210/en.2014-1791)

Moloughney JG, Kim PK, Vega-Cotto NM, Wu C-C, Zhang S, Adlam M, Lynch T, Chou P-C, Rabinowitz JD, Werlen G et al. 2016 mTORC2 responds to glutamine catabolite levels to modulate the hexosamine biosynthesis enzyme GFAT1. Molecular Cell 63 811-826. (https://doi. org/10.1016/j.molcel.2016.07.015)

Murakami M, Ichisaka T, Maeda M, Oshiro N, Hara K, Edenhofer F, Kiyama H, Yonezawa K \& Yamanaka S 2004 mTOR is essential for growth and proliferation in early mouse embryos and embryonic stem cells. Molecular and Cellular Biology 24 6710-6718. (https://doi.org/10.1128/ MCB.24.15.6710-6718.2004)

Nichols J \& Smith A 2012 Pluripotency in the embryo and in culture. Cold Spring Harbor Perspectives in Biology 4 a008128. (https://doi. org/10.1101/cshperspect.a008128)

Nichols J, Zevnik B, Anastassiadis K, Niwa H, Klewe-Nebenius D, Chambers I, Schöler H \& Smith A 1998 Formation of pluripotent stem cells in the mammalian embryo depends on the POU transcription factor Oct4. Cell 95 379-391. (https://doi.org/10.1016/S0092-8674(00)81769-9)

Nichols J, Chambers I, Taga T \& Smith A 2001 Physiological rationale for responsiveness of mouse embryonic stem cells to gp130 cytokines. Development 128 2333-2339.

Nicklin P, Bergman P, Zhang B, Triantafellow E, Wang H, Nyfeler B, Yang H, Hild M, Kung C, Wilson C et al. 2009 Bidirectional transport of amino acids regulates mTOR and autophagy. Cell 136 521-534. (https:// doi.org/10.1016/j.cell.2008.11.044)

Nishioka N, Yamamoto S, Kiyonari H, Sato H, Sawada A, Ota M, Nakao K \& Sasaki H 2008 Tead4 is required for specification of trophectoderm in pre-implantation mouse embryos. Mechanisms of Development 125 270-283. (https://doi.org/10.1016/j.mod.2007.11.002)

Nishioka N, Inoue K, Adachi K, Kiyonari H, Ota M, Ralston A, Yabuta N, Hirahara S, Stephenson RO, Ogonuki N et al. 2009 The hippo signaling pathway components lats and yap pattern Tead4 activity to distinguish mouse trophectoderm from inner cell mass. Developmental Cell 16 398-410. (https://doi.org/10.1016/j.devcel.2009.02.003)

Niwa H, Ogawa K, Shimosato D \& Adachi K 2009 A parallel circuit of LIF signalling pathways maintains pluripotency of mouse ES cells. Nature 460 118-122. (https://doi.org/10.1038/nature08113)

Palaniappan M \& Menon KMJ 2010 Human chorionic gonadotropin stimulates theca-interstitial cell proliferation and cell cycle regulatory proteins by a cAMP-dependent activation of AKT/mTORC1 signaling pathway. Molecular Endocrinology 24 1782-1793. (https://doi. org/10.1210/me.2010-0044)

Palaniappan M \& Menon KMJ 2012 Luteinizing hormone/human chorionic gonadotropin-mediated activation of mTORC1 signaling is required for androgen synthesis by theca-interstitial cells. Molecular Endocrinology 26 1732-1742. (https://doi.org/10.1210/me.2012-1106)
Pearce LR, Huang X, Boudeau J, Pawłowski R, Wullschleger S, Deak M, Ibrahim AFM, Gourlay R, Magnuson MA \& Alessi DR 2007 Identification of protor as a novel Rictor-binding component of mTOR complex-2. Biochemical Journal 405 513-522. (https://doi.org/10.1042/ BJ20070540)

Pearce LR, Sommer EM, Sakamoto K, Wullschleger S \& Alessi DR 2011 Protor-1 is required for efficient mTORC2-mediated activation of SGK1 in the kidney. Biochemical Journal 436 169-179. (https://doi.org/10.1042/ BJ20102103)

Peng X-d, Xu P-Z, Chen M-L, Hahn-Windgassen A, Skeen J, Jacobs J, Sundararajan D, Chen WS, Crawford SE, Coleman KG 2003 Dwarfism, impaired skin development, skeletal muscle atrophy, delayed bone development, and impeded adipogenesis in mice lacking Akt1 and Akt2. Genes and Development 17 1352-1365. (https://doi.org/10.1101/ gad.1089403)

Peterson TR, Sengupta SS, Harris TE, Carmack AE, Kang SA, Balderas E, Guertin DA, Madden KL, Carpenter AE, Finck BN et al. 2011 mTOR complex 1 regulates lipin 1 localization to control the SREBP pathway. Cell 146 408-420. (https://doi.org/10.1016/j.cell.2011.06.034)

Posfai E, Petropoulos S, Oliveira De Barros FR, Schell JP, Jurisica I, Sandberg R, Lanner F \& Rossant J 2017 Position-and hippo signalingdependent plasticity during lineage segregation in the early mouse embryo.

Potter CJ, Pedraza LG \& Xu T 2002 Akt regulates growth by directly phosphorylating Tsc2. Nature Cell Biology 4 658-665. (https://doi. org/10.1038/ncb840)

Puscheck EE, Awonuga AO, Yang Y, Jiang Z \& Rappolee DA 2015 Molecular biology of the stress response in the early embryo and its stem cells. Advances in Experimental Medicine and Biology 843 77-128. (https:// doi.org/10.1007/978-1-4939-2480-6_4)

Ralston A, Cox BJ, Nishioka N, Sasaki H, Chea E, Rugg-Gunn P, Guo G, Robson P, Draper JS \& Rossant J 2010 Gata3 regulates trophoblast development downstream of Tead4 and in parallel to Cdx2. Development 137 395-403. (https://doi.org/10.1242/dev.038828)

Ray RM, Bavaria M \& Johnson LR 2015 Interaction of polyamines and mTOR signaling in the synthesis of antizyme (AZ). Cellular Signalling $\mathbf{2 7}$ 1850-1859. (https://doi.org/10.1016/j.cellsig.2015.06.002)

Renfree MB \& Fenelon JC 2017 The enigma of embryonic diapause. Development 144 3199-3210. (https://doi.org/10.1242/dev.148213)

Rennebeck G, Kleymenova EV, Anderson R, Yeung RS, Artzt K \& Walker CL 1998 Loss of function of the tuberous sclerosis 2 tumor suppressor gene results in embryonic lethality characterized by disrupted neuroepithelial growth and development. PNAS 95 15629-15634. (https://doi. org/10.1073/pnas.95.26.15629)

Roberts DJ, Tan-Sah VP, Smith JM \& Miyamoto S 2013 Akt phosphorylates HK-II at Thr-473 and increases mitochondrial HK-II association to protect cardiomyocytes. Journal of Biological Chemistry 288 23798-23806. (https://doi.org/10.1074/jbc.M113.482026)

Roberts RM, Green JA \& Schulz LC 2016 The evolution of the placenta. Reproduction 152 R179-R189. (https://doi.org/10.1530/REP-16-0325)

Roos S, Jansson N, Palmberg I, Säljö K, Powell TL \& Jansson T 2007 Mammalian target of rapamycin in the human placenta regulates leucine transport and is down-regulated in restricted fetal growth. Journal of Physiology 582 449-459. (https://doi.org/10.1113/jphysiol.2007.129676)

Roos S, Lagerlöf O, Wennergren M, Powell TL \& Jansson T 2009 Regulation of amino acid transporters by glucose and growth factors in cultured primary human trophoblast cells is mediated by mTOR signaling. American Journal of Physiology: Cell Physiology 297 C723-C731. (https://doi.org/10.1152/ajpcell.00191.2009)

Rosario FJ, Jansson N, Kanai Y, Prasad PD, Powell TL \& Jansson T 2011 Maternal protein restriction in the rat inhibits placental insulin, mTOR, and STAT3 signaling and down-regulates placental amino acid transporters. Endocrinology 152 1119-1129. (https://doi.org/10.1210/ en.2010-1153)

Rosario FJ, Kanai Y, Powell TL \& Jansson T 2013 Mammalian target of rapamycin signalling modulates amino acid uptake by regulating transporter cell surface abundance in primary human trophoblast cells. Journal of Physiology 591 609-625. (https://doi.org/10.1113/ jphysiol.2012.238014)

Rosario FJ, Dimasuay KG, Kanai Y, Powell TL \& Jansson T 2016 Regulation of amino acid transporter trafficking by mTORC1 in primary human 
trophoblast cells is mediated by the ubiquitin ligase Nedd4-2. Clinical Science 130 499-512. (https://doi.org/10.1042/CS20150554)

Rosario FJ, Powell TL \& Jansson T 2017 a mTOR folate sensing links folate availability to trophoblast cell function. Journal of Physiology 595 4189-4206. (https://doi.org/10.1113/JP272424)

Rosario FJ, Nathanielsz PW, Powell TL \& Jansson T 2017b Maternal folate deficiency causes inhibition of mTOR signaling, down-regulation of placental amino acid transporters and fetal growth restriction in mice. Scientific Reports 7 3982. (https://doi.org/10.1038/s41598-017-03888-2)

Rosario FJ, Gupta MB, Myatt L, Powell TL, Glenn JP, Cox L \& Jansson T 2019 Mechanistic target of rapamycin complex 1 promotes the expression of genes encoding electron transport chain proteins and stimulates oxidative phosphorylation in primary human trophoblast cells by regulating mitochondrial biogenesis. Scientific Reports 9 246. (https:// doi.org/10.1038/s41598-018-36265-8)

Rovira J, Diekmann F, Ramírez-Bajo MJ, Bañón-Maneus E, Moya-Rull D \& Campistol JM 2012 Sirolimus-associated testicular toxicity: detrimental but reversible. Transplantation Journal 93 874-879. (https://doi. org/10.1097/TP.0b013e31824bf1f0)

Ryu JM \& Han HJ 2011 L-threonine regulates G1/S phase transition of mouse embryonic stem cells via PI3K/Akt, MAPKs, and mTORC pathways. Journal of Biological Chemistry 286 23667-23678. (https:// doi.org/10.1074/jbc.M110.216283)

Sabatini DM, Erdjument-Bromage H, Lui M, Tempst P \& Snyder SH 1994 RAFT1: a mammalian protein that binds to FKBP12 in a rapamycindependent fashion and is homologous to yeast tors. Cell 78 35-43. (https://doi.org/10.1016/0092-8674(94)90570-3)

Sahin P, Gungor-Ordueri NE \& Celik-Ozenci C 2018 Inhibition of mTOR pathway decreases the expression of pre-meiotic and meiotic markers throughout postnatal development and in adult testes in mice. Andrologia 50 e12811 1-11. (https://doi.org/10.1111/and.12811)

Sampath P, Pritchard DK, Pabon L, Reinecke H, Schwartz SM, Morris DR \& Murry CE 2008 A hierarchical network controls protein translation during murine embryonic stem cell self-renewal and differentiation. Cell Stem Cell 2 448-460. (https://doi.org/10.1016/j.stem.2008.03.013)

Sancak Y, Thoreen CC, Peterson TR, Lindquist RA, Kang SA, Spooner E, Carr SA \& Sabatini DM 2007 PRAS40 is an insulin-regulated inhibitor of the mTORC1 protein kinase. Molecular Cell 25 903-915. (https://doi. org/10.1016/j.molcel.2007.03.003)

Sarbassov DD, Ali SM, Kim D-H, Guertin DA, Latek RR, ErdjumentBromage H, Tempst P \& Sabatini DM 2004 Rictor, a novel binding partner of mTOR, defines a rapamycin-insensitive and raptor-independent pathway that regulates the cytoskeleton. Current Biology 14 1296-1302. (https://doi.org/10.1016/j.cub.2004.06.054)

Sarbassov DD, Ali SM, Sengupta S, Sheen J-H, Hsu PP, Bagley AF, Markhard AL \& Sabatini DM 2006 Prolonged rapamycin treatment inhibits mTORC2 assembly and Akt/PKB. Molecular Cell 22 159-168. (https://doi.org/10.1016/j.molcel.2006.03.029)

Saxton RA \& Sabatini DM 2017 MTOR signaling in growth, metabolism, and disease. Cell 168 960-976. (https://doi.org/10.1016/j.cell.2017.02.004)

Schrode N, Xenopoulos P, Piliszek A, Frankenberg S, Plusa B \& Hadjantonakis A-K 2013 Anatomy of a blastocyst: cell behaviors driving cell fate choice and morphogenesis in the early mouse embryo. Genesis 51 219-233. (https://doi.org/10.1002/dvg.22368)

Scognamiglio R, Cabezas-Wallscheid N, Thier MC, Altamura S, Reyes A, Prendergast ÁM, Baumgärtner D, Carnevalli LS, Atzberger A, Haas S et al. 2016 Myc depletion induces a pluripotent dormant state mimicking diapause. Cell 164 668-680. (https://doi.org/10.1016/j. cell.2015.12.033)

Serra ND, Velte EK, Niedenberger BA, Kirsanov O \& Geyer CB 2017 Cellautonomous requirement for mammalian target of rapamycin (Mtor) in spermatogonial proliferation and differentiation in the mouse. Biology of Reproduction 96 816-828. (https://doi.org/10.1093/biolre/iox022)

Settembre C, Zoncu R, Medina DL, Vetrini F, Erdin S, Erdin S, Huyn T, Ferron M, Karsenty G, Vellard MC et al. 2012 A lysosome-to-nucleus signalling mechanism senses and regulates the lysosome via mTOR and TFEB. EMBO Journal 31 1095-1108. (https://doi.org/10.1038/ emboj.2012.32)

Shackelford DB \& Shaw RJ 2009 The LKB1-AMPK pathway: metabolism and growth control in tumour suppression. Nature Reviews Cancer $\mathbf{9}$ 563-575. (https://doi.org/10.1038/nrc2676)
Sherman SL, Curnow EC, Easley CA, Jin P, Hukema RK, Tejada MI, Willemsen R \& Usdin K 2014 Use of model systems to understand the etiology of fragile $\mathrm{X}$-associated primary ovarian insufficiency (FXPOI). Journal of Neurodevelopmental Disorders 6 26. (https://doi. org/10.1186/1866-1955-6-26)

Shiota C, Woo J-T, Lindner J, Shelton KD \& Magnuson MA 2006 Multiallelic disruption of the rictor gene in mice reveals that mTOR complex 2 is essential for fetal growth and viability. Developmental Cell 11 583-589. (https://doi.org/10.1016/j.devcel.2006.08.013)

Silva JV, Cabral M, Correia BR, Carvalho P, Sousa M, Oliveira PF \& Fardilha M 2019 MTOR signaling pathway regulates sperm quality in older men. Cells 8 629. (https://doi.org/10.3390/cells8060629)

Sirotkin AV, Alexa R, Dekanova P, Kadasi A, Stochmalov A, Grossmann R, Alwasel SH \& Harrath AH 2015 The mTOR system can affect basic ovarian cell functions and mediate the effect of ovarian hormonal regulators. International Journal of Pharmacology 11 570-578. (https:// doi.org/10.3923/ijp.2015.570.578)

Skrzypek J \& Krause W 2007 Azoospermia in a renal transplant recipient during sirolimus (rapamycin) treatment. Andrologia 39 198-199. (https:// doi.org/10.1111/j.1439-0272.2007.00787.x)

Smith EM \& Proud CG 2008 cdc2-cyclin B regulates eEF2 kinase activity in a cell cycle- and amino acid-dependent manner. EMBO Journal 27 1005-1016. (https://doi.org/10.1038/emboj.2008.39)

Smith EM, Finn SG, Tee AR, Brownei GJ \& Proud CG 2005 The tuberous sclerosis protein TSC2 is not required for the regulation of the mammalian target of rapamycin by amino acids and certain cellular stresses. Journal of Biological Chemistry 280 18717-18727. (https://doi.org/10.1074/jbc. M414499200)

Stambolic V, Suzuki A, de la Pompa JL, Brothers GM, Mirtsos C, Sasaki T, Ruland J, Penninger JM, Siderovski DP \& Mak TW 1998 Negative regulation of PKB/Akt-dependent cell survival by the tumor suppressor PTEN. Cell 95 29-39. (https://doi.org/10.1016/S0092-8674(00)81780-8)

Tai C-I \& Ying Q-L 2013 Gbx2, a LIF/Stat3 target, promotes reprogramming to and retention of the pluripotent ground state. Journal of Cell Science 126 1093-1098. (https://doi.org/10.1242/jcs.118273)

Tanwar PS, Kaneko-tarui T, Zhang LH \& Teixeira JM 2012 Altered LKB1/AMPK/TSC1/TSC2/mTOR signaling causes disruption of Sertoli cell polarity and spermatogenesis. Human Molecular Genetics 21 4394-4405. (https://doi.org/10.1093/hmg/dds272)

Tee AR, Manning BD, Roux PP, Cantley LC \& Blenis J 2003 Tuberous sclerosis complex gene products, tuberin and hamartin, control mTOR signaling by acting as a GTPase-activating protein complex toward Rheb. Current Biology 13 1259-1268. (https://doi.org/10.1016/S09609822(03)00506-2)

Tee WW, Shen SS, Oksuz O, Narendra V \& Reinberg D 2014 ERK1/2 activity promotes chromatin features and RNAPII phosphorylation at developmental promoters in mouse ESCs. Cell 156 678-690. (https:// doi.org/10.1016/j.cell.2014.01.009)

Tesar PJ, Chenoweth JG, Brook FA, Davies TJ, Evans EP, Mack DL, Gardner RL \& McKay RDG 2007 New cell lines from mouse epiblast share defining features with human embryonic stem cells. Nature $\mathbf{4 4 8}$ 196-199. (https://doi.org/10.1038/nature05972)

Tschopp O, Yang Z-Z, Brodbeck D, Dummler BA, HemmingsMieszczak M, Watanabe T, Michaelis T, Frahm J \& Hemmings BA 2005 Essential role of protein kinase B gamma (PKB gamma/Akt3) in postnatal brain development but not in glucose homeostasis. Development 132 2943-2954. (https://doi.org/10.1242/dev.01864)

Tsukamoto S, Kuma A, Murakami M, Kishi C, Yamamoto A \& Mizushima N 2008 Autophagy is essential for preimplantation development of mouse embryos. Science 321 117-120. (https://doi.org/10.1126/ science.1154822)

Vaughan OR, Rosario FJ, Powell TL \& Jansson T 2017 Regulation of placental amino acid transport and fetal growth. Progress in Molecular Biology and Translational Science 145 217-251. (https://doi.org/10.1016/ bs.pmbts.2016.12.008)

Villalobos-Labra R, Silva L, Subiabre M, Araos J, Salsoso R, Fuenzalida B, Sáez T, Toledo F, González M, Quezada C et al. 2017 Akt/mTOR role in human foetoplacental vascular insulin resistance in diseases of pregnancy. Journal of Diabetes Research 2017 1-13. (https://doi. org/10.1155/2017/5947859)

Wadhwa PD, Buss C, Entringer S \& Swanson JM 2009 Developmental origins of health and disease: brief history of the approach and current 
focus on epigenetic mechanisms. Seminars in Reproductive Medicine 27 358-368. (https://doi.org/10.1055/s-0029-1237424)

Wang S, Xia P, Ye B, Huang G, Liu J \& Fan Z 2013 Transient activation of autophagy via Sox2-mediated suppression of mTOR is an important early step in reprogramming to pluripotency. Cell Stem Cell 13 617-625. (https://doi.org/10.1016/j.stem.2013.10.005)

Wang X, Burghardt RC, Romero JJ, Hansen TR, Wu G \& Bazer FW 2015 Functional roles of arginine during the peri-implantation period of pregnancy. III. Arginine stimulates proliferation and interferon tau production by ovine trophectoderm cells via nitric oxide and polyamineTSC2-mTOR signaling pathways. Biology of Reproduction 92 75-71. (https://doi.org/10.1095/biolreprod.114.125989)

Wang C, Wang Z, Xiong Z, Dai H, Zou Z, Jia C, Bai X \& Chen Z 2016 mTORC1 activation promotes spermatogonial differentiation and causes subfertility in mice. Biology of Reproduction 95 97-97. (https://doi. org/10.1095/biolreprod.116.140947)

Weinberger L, Ayyash M, Novershtern N \& Hanna JH 2016 Dynamic stem cell states: naive to primed pluripotency in rodents and humans. Nature Reviews: Molecular Cell Biology 17 155-169. (https://doi.org/10.1038/ nrm.2015.28)

World Health Organization 2010 Examination and Processing of Human Semen, 5th ed. Geneva: WHO Press.

Wray J, Kalkan T, Gomez-Lopez S, Eckardt D, Cook A, Kemler R \& Smith A 2011 Inhibition of glycogen synthase kinase-3 alleviates Tcf3 repression of the pluripotency network and increases embryonic stem cell resistance to differentiation. Nature Cell Biology 13 838-845. (https:// doi.org/10.1038/ncb2267)

Xu H, Shen L, Chen X, Ding Y, He J, Zhu J, Wang Y \& Liu X 2016 mTOR/ p70s6K promotes spermatogonia proliferation and spermatogenesis in Sprague Dawley rats. Reproductive Biomedicine Online 32 207-217. (https://doi.org/10.1016/j.rbmo.2015.11.007)

Yaba A, Bianchi V, Borini A \& Johnson J 2008 A putative mitotic checkpoint dependent on mTOR function controls cell proliferation and survival in ovarian granulosa cells. Reproductive Sciences 15 128-138. (https://doi. org/10.1177/1933719107312037)

Yagi R, Kohn MJ, Karavanova I, Kaneko KJ, Vullhorst D, DePamphilis ML \& Buonanno A 2007 Transcription factor TEAD4 specifies the trophectoderm lineage at the beginning of mammalian development. Development 134 3827-3836. (https://doi.org/10.1242/dev.010223)

Yamanaka Y, Lanner F \& Rossant J 2010 FGF signal-dependent segregation of primitive endoderm and epiblast in the mouse blastocyst. Development 137 715-724. (https://doi.org/10.1242/dev.043471)

Yang Z-Z, Tschopp O, Di-Poï N, Bruder E, Baudry A, Dümmler B, Wahli W \& Hemmings BA 2005 Dosage-dependent effects of Akt1/protein kinase Balpha (PKBalpha) and Akt3/PKBgamma on thymus, skin, and cardiovascular and nervous system development in mice. Molecular and Cellular Biology 25 10407-10418. (https://doi.org/10.1128/ MCB.25.23.10407-10418.2005)

Ye S, Li P, Tong C \& Ying Q-L 2013 Embryonic stem cell self-renewal pathways converge on the transcription factor Tfcp2l1. EMBO Journal 32 2548-2560. (https://doi.org/10.1038/emboj.2013.175)

Ying QL, Wray J, Nichols J, Batlle-Morera L, Doble B, Woodgett J, Cohen P \& Smith A 2008 The ground state of embryonic stem cell self-renewal. Nature 453 519-523. (https://doi.org/10.1038/nature06968)

Yoshioka K, Yoshida K, Cui H, Wakayama T, Takuwa N, Okamoto Y, Du W, Qi X, Asanuma K, Sugihara K et al. 2012 Endothelial PI3K-C2 $\alpha$, a class II $\mathrm{PI3K}$, has an essential role in angiogenesis and vascular barrier function. Nature Medicine 18 1560-1569. (https://doi.org/10.1038/nm.2928)

Young RA 2011 Control of the embryonic stem cell state. Cell $\mathbf{1 4 4}$ 940-954. (https://doi.org/10.1016/j.cell.2011.01.032)

Yu J, Yaba A, Kasiman C, Thomson T \& Johnson J 2011 mTOR controls ovarian follicle growth by regulating granulosa cell proliferation. PLOS ONE 6 e21415. (https://doi.org/10.1371/journal.pone.0021415)

Yu J, Thomson TC \& Johnson J 2012 Cross talk between estradiol and mTOR kinase in the regulation of ovarian granulosa proliferation. Reproductive Sciences 19 143-151. (https://doi.org/10.1177/1933719111424447)

Yu JSL, Ramasamy TS, Murphy N, Holt MK, Czapiewski R, Wei S-K \& Cui W $2015 \mathrm{PI} 3 \mathrm{~K} / \mathrm{mTORC} 2$ regulates TGF- $\beta$ /activin signalling by modulating Smad2/3 activity via linker phosphorylation. Nature Communications 6 7212. (https://doi.org/10.1038/ncomms8212)

Yung H, Calabrese S, Hynx D, Hemmings BA, Cetin I, Charnock-Jones DS \& Burton GJ 2008 Evidence of placental translation inhibition and endoplasmic reticulum stress in the etiology of human intrauterine growth restriction. American Journal of Pathology 173 451-462. (https:// doi.org/10.2353/ajpath.2008.071193)

Zeng X, Mao X, Huang Z, Wang F, Wu G \& Qiao S 2013 Arginine enhances embryo implantation in rats through $\mathrm{PI} 3 \mathrm{~K} / \mathrm{PKB} / \mathrm{mTOR} / \mathrm{NO}$ signaling pathway during early pregnancy. Reproduction 145 1-7. (https://doi. org/10.1530/REP-12-0254)

Zhang HH, Huang J, Düvel K, Boback B, Wu S, Squillace RM, Wu C-L \& Manning BD 2009 Insulin stimulates adipogenesis through the AktTSC2-mTORC1 pathway. PLoS ONE 4 e6189. (https://doi.org/10.1371/ journal.pone.0006189)

Zhang X, Li L, Xu J, Wang N, Liu W, Lin X, Fu Y \& Luo L 2013 Rapamycin preserves the follicle pool reserve and prolongs the ovarian lifespan of female rats via modulating mTOR activation and sirtuin expression. Gene 523 82-87. (https://doi.org/10.1016/j.gene.2013.03.039)

Zhang J, Ratanasirintrawoot S, Chandrasekaran S, Wu Z, Ficarro SB, Yu C, Ross CA, Cacchiarelli D, Xia Q, Seligson M et al. 2016 LIN28 regulates stem cell metabolism and conversion to primed pluripotency. Cell Stem Cell 19 66-80. (https://doi.org/10.1016/j.stem.2016.05.009)

Zhang C, Liu X-R, Cao Y-C, Tian J-L, Zhen D, Luo X-F, Wang X-M, Tian J-H \& Gao J-M 2017a Mammalian target of rapamycin/eukaryotic initiation factor 4F pathway regulates follicle growth and development of theca cells in mice. Reproduction, Fertility and Development 29 768. (https:// doi.org/10.1071/RD15230)

Zhang QX, Na Q \& Song W 2017b Altered expression of mTOR and autophagy in term normal human placentas. Romanian Journal of Morphology and Embryology 58 517-526.

Zhao X, Lu S, Nie J, Hu X, Luo W, Wu X, Liu H, Feng Q, Chang Z, Liu Y et al. 2014 Phosphoinositide-dependent kinase 1 and mTORC2 synergistically maintain postnatal heart growth and heart function in mice. Molecular and Cellular Biology 34 1966-1975. (https://doi. org/10.1128/MCB.00144-14)

Zheng B, Wang J, Tang L, Shi J \& Zhu D 2017 a mTORC1 and mTORC2 play different roles in regulating cardiomyocyte differentiation from embryonic stem cells. International Journal of Developmental Biology 61 65-72. (https://doi.org/10.1387/ijdb.160207dz)

Zheng B, Wang J, Tang L, Tan C, Zhao Z, Xiao Y, Ge R \& Zhu D 2017 b Involvement of Rictor/mTORC2 in cardiomyocyte differentiation of mouse embryonic stem cells in vitro. International Journal of Biological Sciences 13 110-121. (https://doi.org/10.7150/ijbs.16312)

Zhou J, Su P, Wang L, Chen J, Zimmermann M, Genbacev O, Afonja O, Horne MC, Tanaka T, Duan E et al. 2009 mTOR supports long-term selfrenewal and suppresses mesoderm and endoderm activities of human embryonic stem cells. PNAS 106 7840-7845. (https://doi.org/10.1073/ pnas.0901854106)

Zhou X, Takatoh J \& Wang F 2011 The mammalian class 3 PI3K (PIK3C3) is required for early embryogenesis and cell proliferation. PLOS ONE 6 e16358. (https://doi.org/10.1371/journal.pone.0016358)

Zhou Z, Shiraiwa T, Ohbo K, Sada A, Wu Q, Hasegawa K, Saba R \& Saba Y 2015 RNA binding protein Nanos2 organizes post-transcriptional buffering system to retain primitive state of mouse spermatogonial stem cells. Developmental Cell 34 96-107. (https://doi.org/10.1016/j. devcel.2015.05.014)

Ziomek CA \& Johnson MH 1980 Cell surface interaction induces polarization of mouse 8-cell blastomeres at compaction. Cell $2 \mathbf{1}$ 935-942. (https://doi.org/10.1016/0092-8674(80)90457-2)

Zuber J, Anglicheau D, Elie C, Bererhi L, Timsit M, Mamzer-Bruneel M, Ciroldi M, Martinez F, Snanoudj R, Hiesse C et al. 2008 Sirolimus may reduce fertility in male renal transplant recipients. American Journal of Transplantation 8 1471-1479. (https://doi.org/10.1111/j.16006143.2008.02267.x)

Zylicz JJ, Dietmann S, Günesdogan U, Hackett JA, Cougot D, Lee C \& Surani MA 2015 Chromatin dynamics and the role of G9a in gene regulation and 1 enhancer silencing during early mouse development. eLife 4 e09571. (https://doi.org/10.7554/eLife.09571)

Received 6 February 2019

First decision 19 March 2019

Revised manuscript received 22 November 2019

Accepted 29 November 2019 